\title{
Analytical solutions and 3D numerical analyses of a shallow tunnel excavated in weak ground: a case from Turkey
}

\author{
Ebu Bekir Aygar ${ }^{1}$ and Candan Gokceoglu $2^{2^{*}}$ (D)
}

\author{
${ }^{*}$ Correspondence: \\ cgokce@hacettepe.edu.tr \\ ${ }^{2}$ Department of Geological \\ Engineering, Hacettepe \\ University, Beytepe, \\ 06800 Ankara, Turkey \\ Full list of author information \\ is available at the end of the \\ article
}

\begin{abstract}
Due to the increasing population and resulting transportation needs, the number of subway and high-speed railway projects has also increased. The geometric constraints of such projects have caused many tunnels to be built in weak ground. Thus, weak ground tunnelling has attracted the attention of tunnel engineers and researchers. The main purposes of this study are to analyse the T4 tunnel excavated in weak ground and to compare the results obtained from the analytical solutions and 3D numerical analyses. This study specifically considers the T4 tunnel support system used in the Ankara İzmir High Speed Railway Project (Afyonkarahisar-Banaz Section). The T4 tunnel route encounters weak ground composed of layers of extremely weak mudstone, clayey sand, weakly cemented sandstone, and silty-clay matrix with pebbles. The tunnel overburden ranges from 10 to $35 \mathrm{~m}$, which is shallow. After the excavation work of the T4 tunnel, severe deformation and critical stability problems in the shallow part (where the overburden is approximately $10 \mathrm{~m}$ ) were encountered inside the tunnel, leading to a halt in construction. This was followed by revisions to the tunnel support system, leading to successful completion of the tunnel excavation. Numerical simulations of the low overburden section are performed using the commercially available FLAC3D program that uses the finite difference method. The characteristics of insufficient/ineffective support systems and adequate support systems for shallow tunnels excavated through weak ground are discussed in this study. Additionally, problems that pertain to the tunnel itself and its support system are discussed. The results of the 3D numerical analyses and analytical solutions are compared, and the advantages of 3D numerical analyses are discussed. The importance and necessity of tunnel face stability and roof stability for tunnel stability in weak ground is illustrated. Consequently, solutions based on analytical and numerical analyses are presented, and the analysis methodology and solutions proposed in the study can help guide weak ground tunnelling design and evaluation.
\end{abstract}

Keywords: Shallow tunnel, Weak ground, Tunnel collapse, Tunnel support system, 3D numerical analysis, Analytical solution the source, provide a link to the Creative Commons licence, and indicate if changes were made. The images or other third party material in this article are included in the article's Creative Commons licence, unless indicated otherwise in a credit line to the material. If material is not included in the article's Creative Commons licence and your intended use is not permitted by statutory regulation or exceeds the permitted use, you will need to obtain permission directly from the copyright holder. To view a copy of this licence, visit http://creativeco mmons.org/licenses/by/4.0/. 


\section{Introduction}

Frequently, problems encountered in the excavation of road and railway tunnels worldwide arise in those excavated under shallow overburden thicknesses of weak soils. Due to the strict technical standards for high-speed railways and expressways, i.e., due to the limited height of cutting excavation, the construction of shallow tunnels has become increasingly frequent [1]. The most common problems encountered in these tunnels are face shifts and discharges from the ceiling. Such problems are usually caused by the slippage of tunnel faces along these shallow tunnels. In such situations, tunnel excavation should be interrupted, and complex engineering approaches are required to safely pass through the collapse-prone zones; settlements along the tunnel route cause greater problems. Another important factor in the excavation of tunnels in weak ground is the interaction of the portal slopes with the ongoing tunnel excavation work. After the completion of the portal excavation, the deformations that may occur during tunnel excavation tend to affect the portal region and can cause stability problems of the tunnel and/or portals. A significant problem that occurs in shallow tunnels excavated through weak ground in residential areas is the negative effect of excavation under the buildings along the tunnel route. In such cases, excavation methods and tunnel supports that do not allow any deformations during the tunnel excavation phase should be implemented. If the tunnel is excavated based on the New Austrian Tunnelling Method (NATM) principles, face and ceiling supports must be implemented, in addition to ground reinforcement. Assis [2] stated the limitations and difficulties of urban tunnelling. In particular, he examined failure behaviour and surface displacements along shallow tunnels. Gupta [3] described the problems encountered on Line 3 of the Mumbai Subway. Hoek [4] investigated ground control strategies for underground structures. 'Squeezing' problems were encountered in Venezuela's Yacambu-Quibor Tunnel (squeezing occurred where the height of the overburden increased to $1270 \mathrm{~m}$ ), and the tunnel passed through weak lithological units of graphitic phyllite. The problems were obviated by implementing $60-\mathrm{cm}$ thick coatings containing sliding joints reinforced with steel shafts and steel ribs [4-6]. Rubiralta et al. [7] examined the problems encountered during the excavation with a tunnel boring machine (TBM) on the third line of Sofia Metro, an 8-km long project that included seven stations. An earth pressure balance (EPB) TBM was selected for the main tunnel excavation in this project.

Furthermore, Heslop [8] investigated design and construction issues in tunnels excavated beneath urban areas and explained their relevant problems. Li et al. [9] investigated the collapse factors of a shallow tunnel through Chaoyang Mountain of Qingdao, China, by simulation and field measurement. Astore and Pradella [10] studied the Anatolian Subway, which was constructed between Kadıköy and Kartal in Istanbul, along a length of $21.7 \mathrm{~km}$ with 16 stations. This subway is located mainly in the densely populated Anatolian part of İstanbul beneath the E5/D100 motorway. The tunnels are located under a cover thickness of 25-35 m. Taromi et al. [11] discussed the collapse and solution methods for the portal section of the 10.6-km long Sabzkuh water transmission tunnel. A collapse of the tunnel occurred following a 35-m tunnel excavation at the entrance portal using conventional methods (NATM) owing to geological conditions and inappropriate excavation procedures. The collapse in this section of the tunnel caused interactions between the portal and the tunnel. Within the 
scope of work conducted by Antony et al. [12], a 10.7-km-long section of the Hong Kong West Drainage Tunnel (HKWDT) with a diameter of $8.2 \mathrm{~m}$ was investigated. The units through which the tunnel passes are generally granite and tuff containing 30 potential fault zones; the tunnel route runs parallel to the Sandy Bay fault, and a double-shield TBM was selected for this project. In the fault zones, the TBM was converted to a single-shield TBM [12]. Kovari et al. [13] examined TBM usage under weak ground conditions beneath residential areas and stated that many large tunnels were being excavated with only a shallow cover under buildings, bridges, and roads, which could not only trigger settlements and large-scale collapses but also affect surface conditions.

The NATM, which aims to maximize the self-carrying capacity of overburden, was introduced in the 1960s by Rabcewicz [14-16]. The application range of the NATM is from weak ground to hard rock, and this method has been used in many tunnels, including tunnels that are currently under construction. Whittaker and Frith [17] summarized the factors affecting the problems of weak ground for select support systems. Goricki et al. [18] studied tunnel support systems for fault transitions and identified five main factors for support system selection and implementation. Sulem and Manh [19] and Bonini and Barla [20] examined the congestion problems of St-Martin-la Porte galleries excavated within the scope of the Lyon-Turin Railway Project and discussed the proposed solutions. The problems experienced in the Zhegushan, Laodongshan, Minyazi, Xiangshan, Yingfeng, and Yezhping tunnels excavated in China and the precautions taken against these problems are explained in detail by Wang et al. [21]. For the Bolu Tunnel of the Istanbul-Ankara Motorway, problems surfaced during excavation, including deformations in the support systems related to compression and swelling [22] and a collapse after the 12th November 1999 Düzce earthquake. In related studies, failed segments were identified, and revisions were made to the NATM method [22]. The causes of the collapse of the Bolu Tunnel after the Düzce earthquake were discussed by Aygar [23]. Aygar and Gokceoglu [24, 25] examined the effects of the squeezing and swelling characteristics of soil units and fault zones on tunnel support systems and stated the requirement of a rigid support system for those types of ground units. Aygar and Gokceoglu [26] have also emphasized that providing the stability of the tunnel face and ceiling is the most crucial factor of support systems for large-diameter urban railway tunnels excavated through weak units under a shallow overburden thickness. Additionally, the face stability of shallow tunnels excavated in weak ground conditions has been considered by several researchers $[1,27-31]$ due to the importance of face stability for tunnel stability. As mentioned by Morovatdar et al. [32], tunnelling at shallow depths in soft grounds gives rise to concerns associated with tunnel instability. Huang et al. [33] analysed the deformation response induced by surcharge loading above shallow shield tunnels in soft soil by employing 3D numerical analyses.

Based on the brief literature review described above, it can be stated that every tunnel project has complexities and requires specific methodologies. In other words, each tunnel case should be studied in detail considering its specific geological, geotechnical and project characteristics. The purposes of the present study are to analyse and compare the results obtained from analytical solutions and 3D numerical analyses of a shallow railway tunnel excavated in difficult ground conditions. 


\section{Tunnel specifications}

The analyses in the study were performed on the entrance portal section of the T4 tunnel $(1260 \mathrm{~m})$ excavated within the scope of the Ankara-İzmir High Speed Railway Project in Turkey. T4 is a shallow tunnel drilled through weak ground conditions; therefore, it is important for tunnelling studies. The $\mathrm{T} 4$ tunnel was excavated beneath a maximum overburden thickness of $35 \mathrm{~m}$. The tunnel passes mainly through interbedded gravelsand-clay layers. Prior to project revisions, several tunnel face stability problems and deformations were observed along the tunnel route. Through a set of revisions and proposed solutions, tunnel excavations were completed successfully. A location map and an aerial view of the T4 tunnel are shown in Figs. 1 and 2. The project begins at the entrance portal ( $\mathrm{km}: 209+615)$, continues at a slope of $1.6 \%$, and ends at the exit portal $(\mathrm{km}: 210+875)$. The altitudes of the entrance and exit portals are $1223.95 \mathrm{~m}$ and $1243.73 \mathrm{~m}$, respectively.

\section{Geological and geotechnical conditions}

As shown in the geological cross-section given in Fig. 3, the tunnel was excavated mainly through the lower Miocene aged Hacibekir Formation comprising gravel in a silt-clay matrix, extremely weak sandstone, and mudstone-clayey sandstone [34]. Evaluation of the tunnel was performed via the mechanical properties of the rock at the entrance portal $(\mathrm{km}: 210+24)$, which is shallow overburden and cohesionless ground.

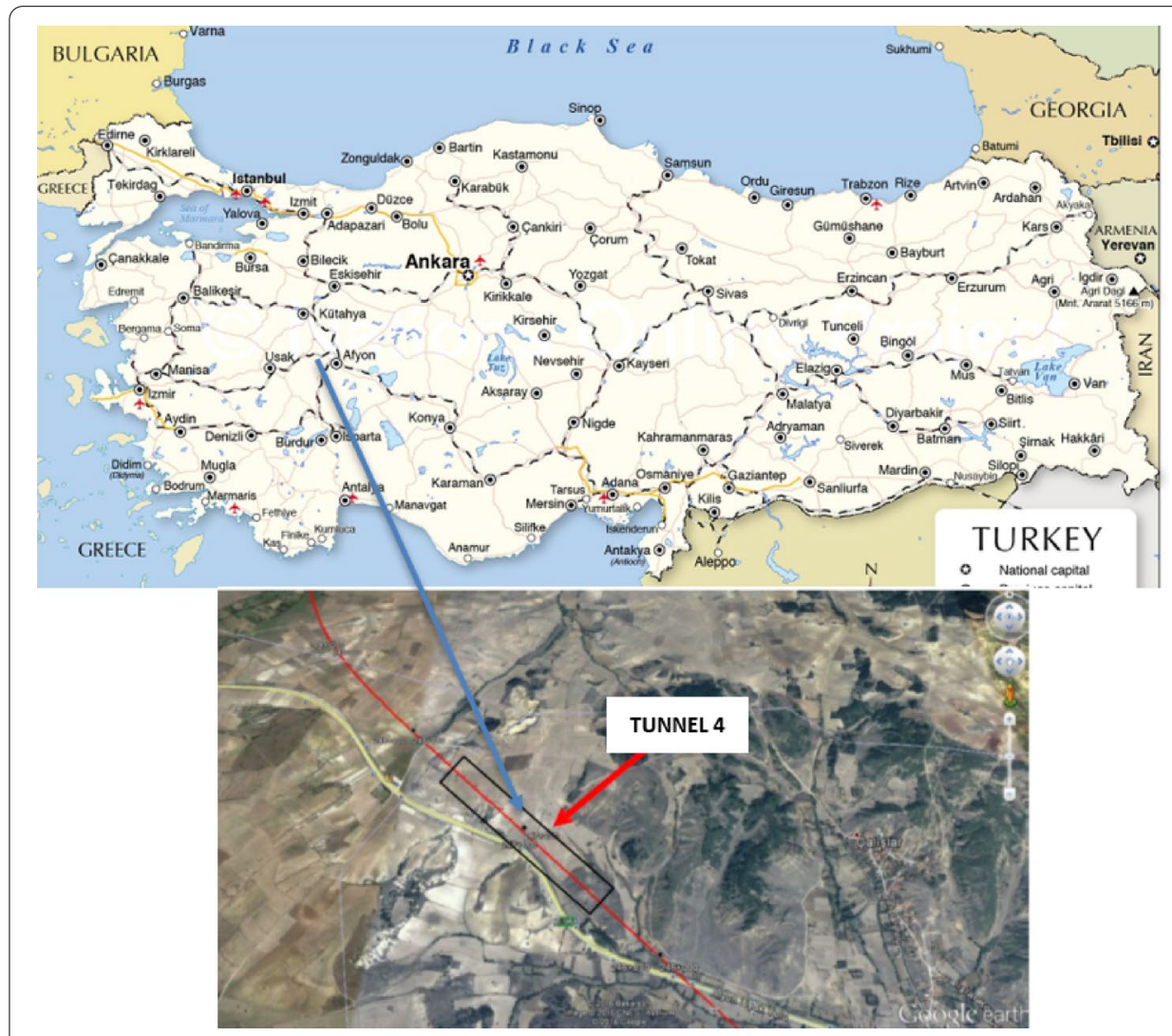

Fig. 1 Map of the location of the T4 tunnel 


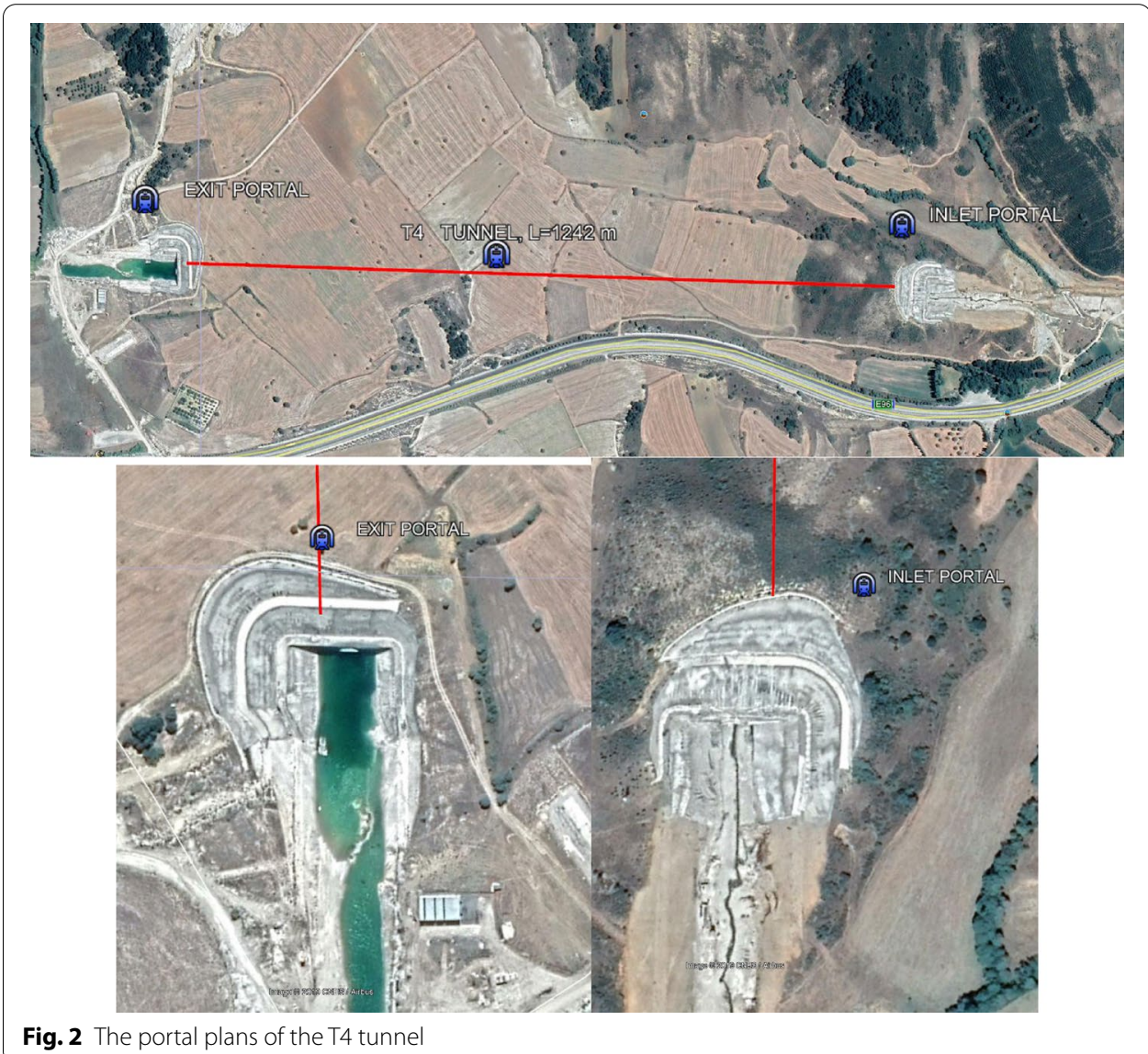

In the present study, the entrance portal of $\mathrm{T} 4$ is analysed because this part of the tunnel presents serious geotechnical difficulties and requires special design. The section of the entrance portal at $\mathrm{km}: 210+150$ demonstrates shallow tunnel characteristics with a minimum overburden thickness of $10 \mathrm{~m}$, where weakly cemented sandstone is intercalated with clayey sand. Based on the material acquired from boreholes SK-246 + 415, SK-246+000, and SK-246+700 drilled in this section of the tunnel and site investigation data, geotechnical design parameters were determined for the units. There is a high potential of flow and slide cases either at the tunnel face or tunnel ceiling. At the parts of the tunnel through low-cohesion gravel in a siltclay matrix (Figs. 4 and 5), the C4 rock class was specified according to the NATM method.

This section of the tunnel was excavated through low cohesive gravel in a silt-clay matrix; therefore, effective soil parameters were proposed. The standard penetration test (SPT) values obtained for boreholes SK-246+415 and SK-246+700 were not representative because of the gravel unit (Figs. 4 and 5). To achieve a safe design, a single parameter was assigned to the units. According to the SPT-N-effective shear strength relation introduced by Carter and Bentley [35], if the SPT-N value of clayey sand units is assumed to be 35 , the corresponding angle of internal friction is $37^{\circ}$. Based on the clay content of the unit, the values were optimized as $c^{\prime}=5 \mathrm{kPa}$ and 

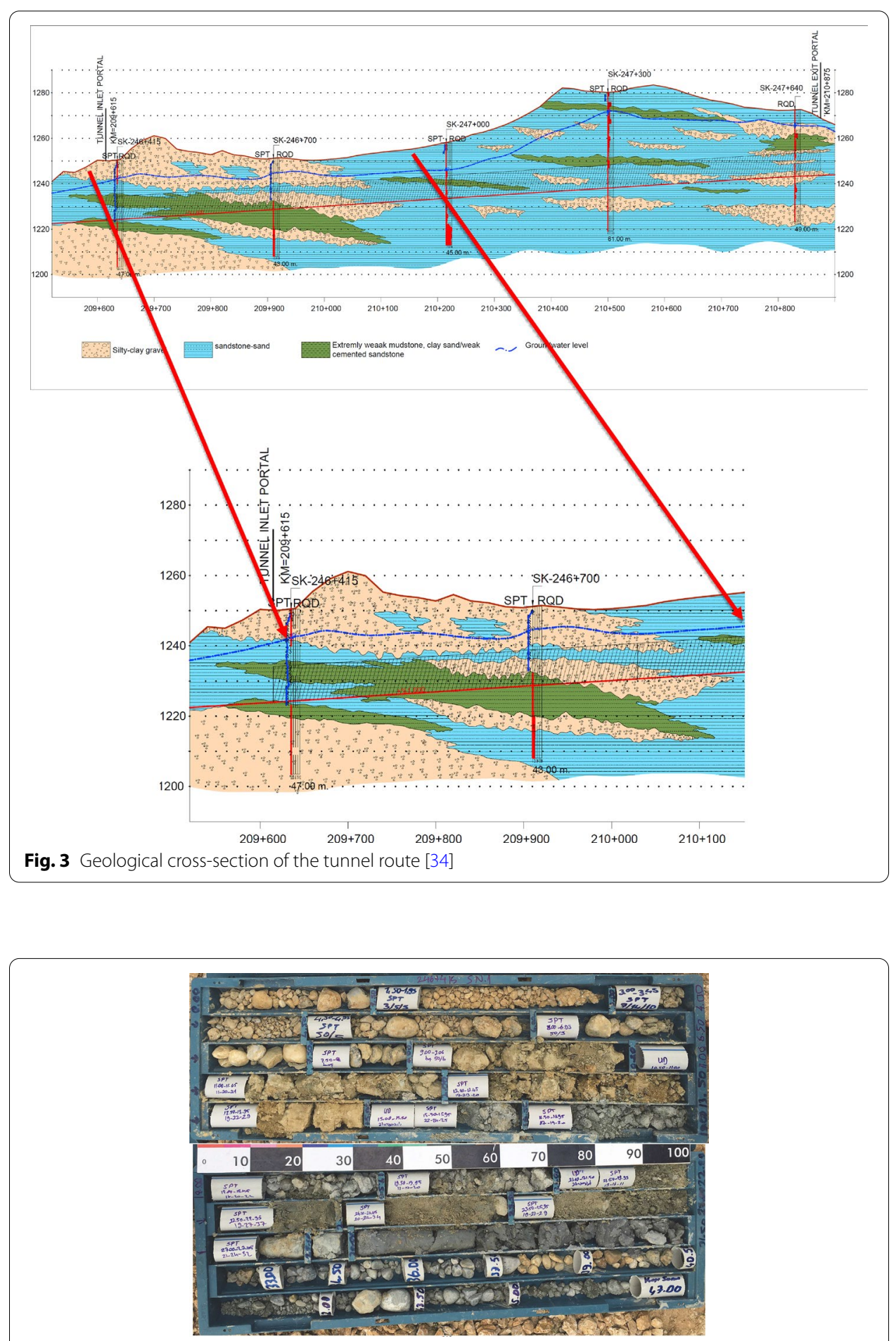

Fig. 4 Core box photographs from SK-246 + 415 [34] 


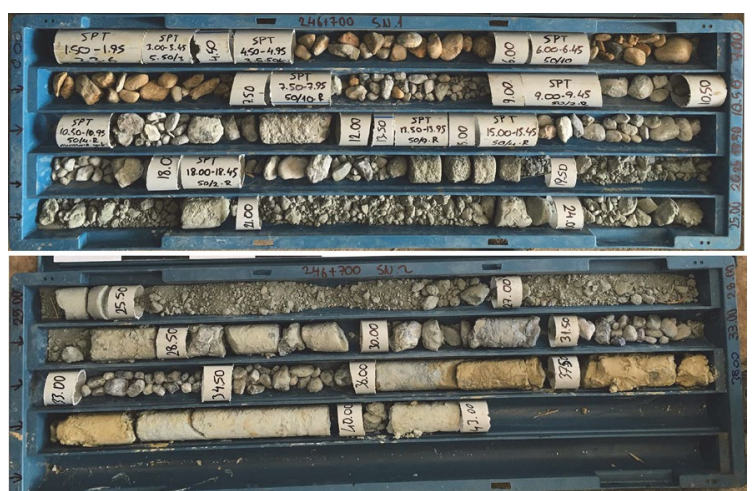

Fig. 5 Core box photographs from SK-246+ 700 [34]

Table 1 Geotechnical parameters used for the analyses

\begin{tabular}{llll}
\hline Cohesion $(\mathrm{kPa})$ & Internal Friction Angle $\left(^{\circ}\right)$ & Deformation Modulus (MPa) & Overburden $(\mathrm{m})$ \\
\hline 5 & 35 & 80 & 15 \\
\hline
\end{tabular}

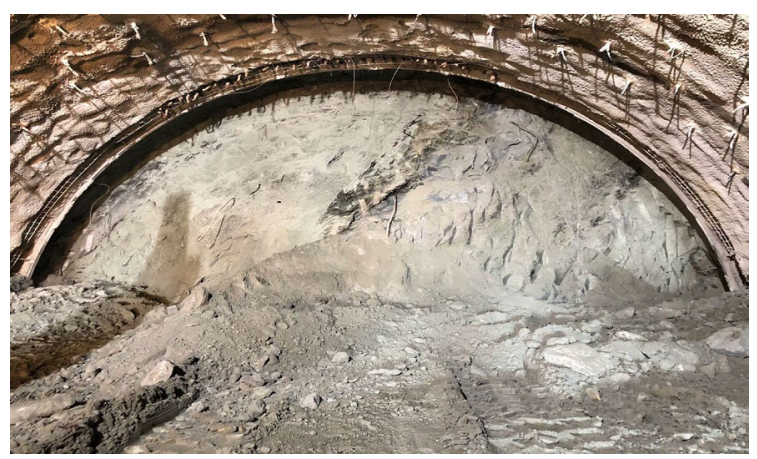

Fig. 6 A close view of the face excavated in the silt-clay unit

$\varnothing^{\prime}=35^{\circ}$. The geotechnical parameters used in the analyses are given in Table 1 , and the face, which is excavated in a silt-clay unit, is shown in Fig. 6.

\section{Tunnel support design methods}

There are basically 3 main methods used to determine tunnel support systems: empirical methods, analytical methods and numerical methods [36-39]. Each of these methods has its advantages and disadvantages; thus, support design can be performed by evaluating these three methods as a whole. Closed-form solutions can be used during preliminary design, but numerical programs should be used for detailed analysis. In this study, the FLAC3D [40] program was used to perform 3D analyses to determine the relationship between tunnel excavation levels. In addition, umbrella and face soil nails can be described into the model, and the face stability of the tunnel can be assessed. In 3D programs, the inner lining concrete can be defined in the interlayer concrete model, and 
changes that may occur during tunnel excavation can be examined. Additionally, analytical solutions were carried out, and the results were compared.

\section{Evaluation of preliminary tunnel support systems}

Zhang et al. [41] proposed a theoretical model for the stability analysis of a reinforced tunnel face in cohesive-frictional soils with the limit equilibrium method and strength reduction technique. The analytical model for face stability proposed by Zhang et al. [41] agreed well with the corresponding 3D numerical analysis results; hence, analytical models are extremely important for tunnel design and analysis. Lyu et al. [42] suggested an analytical approach to calculate the pressure distribution around a twin tunnel in layered strata. Fang et al. [43] proposed an analytical solution for loosening earth pressure above a shallow tunnel in unsaturated ground. As shown by these examples, analytical solutions are still useful tools for analysing tunnel deformations and ground reactions. In the present study, analytical solutions (closed-form solutions) are carried out to determine tunnel support systems and to investigate the ground and rock behaviour, presumably, for preliminary evaluation prior to numerical analyses [44-46]. In these analyses, it is assumed that the tunnel is circular and under hydrostatic conditions, where the in situ vertical and horizontal stresses are equal [45]. In Fig. 7, $\mathrm{p}_{0}$, the internal support pressure $\left(\mathrm{p}_{\mathrm{i}}\right)$, tunnel radius $\left(\mathrm{r}_{0}\right)$ and plastic zone radius $\left(\mathrm{r}_{\mathrm{p}}\right)$ are shown under hydrostatic stress.

In Table 2 [44-46], closed-form solutions are given according to the Mohr-Coulomb failure criterion under hydrostatic stress.

The ground parameters of the analysed tunnel portal section are given in Table 1. In this section, preliminary comments are made on the behaviour of the ground and tunnel support systems. The field stress is $\mathrm{p}_{0}=0.020 \times 14=0.28 \mathrm{MPa} ; \sigma_{\mathrm{cm}}$ is calculated to be $0.02 \mathrm{MPa}$.

The ratio of rock mass strength $\left(\sigma_{\mathrm{cm}}=0.02 \mathrm{MPa}\right)$ to in situ stress $\left(\mathrm{p}_{0}=0.28\right)\left(\sigma_{\mathrm{cm}} / \mathrm{P}_{0}\right)$ is 0.07 . In addition, the plastic zone radius is $r_{p}=5.62 \mathrm{~m}$ according to Eq. 9 as shown in Table 2. If the unit strain occurring around the tunnel is $\varepsilon$, it is calculated with Eq. 8 in Table 2. Here, $\varepsilon$ is $40 \%$. Separately, $u_{i}=2.65 \mathrm{~m}$ occurs in the unsupported state, indicating that the tunnel collapses in that state. In Fig. 8, the relationship between

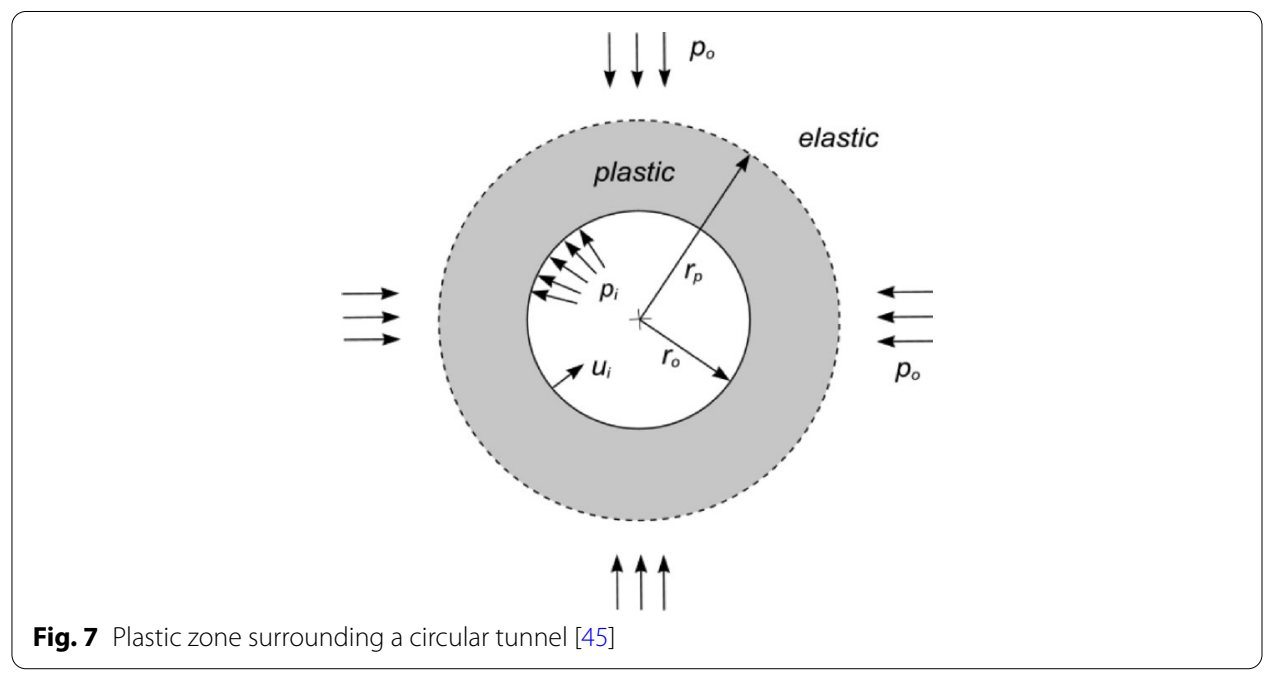


Table 2 Closed-form solution equations [44-46]

\begin{tabular}{|c|c|c|c|}
\hline $\begin{array}{l}\text { Mohr-Cou- } \\
\text { lomb crite- } \\
\text { rion (1) }\end{array}$ & $\sigma_{1}^{\prime}=\sigma_{c m}+k \sigma_{3}^{\prime}$ & $\begin{array}{l}\text { Radius of the } \\
\text { plastic zone } \\
\text { rp when } \\
\mathrm{p}_{\mathrm{i}}=0(6)\end{array}$ & $r_{p}=r_{0}\left[\left(\frac{2\left(p_{0}(k-1)+\sigma_{c m}\right)}{(1+k)\left((k-1) p_{i}+\sigma_{c m}\right)}\right)\right]^{\frac{1}{k-1}}$ \\
\hline $\begin{array}{l}\text { The uniaxial } \\
\text { compressive } \\
\text { strength of } \\
\text { the rock mass } \\
\sigma_{\mathrm{cm}}(2)\end{array}$ & $\sigma_{c m}=\frac{2 c^{\prime} \cos \phi^{\prime}}{1-\sin \phi^{\prime}}$ & $\begin{array}{l}\text { Inward radial } \\
\text { displacement } \\
u_{i p}(7)\end{array}$ & uip $=\left(\frac{r o(1+\vartheta)}{E m}\right)\left[2(1-\vartheta)(p 0-p c r)\left(\frac{r p}{r 0}\right)^{2}-(1-2 \vartheta)(p 0-p i)\right]$ \\
\hline $\begin{array}{l}\text { The slope } k \text { of } \\
\sigma_{1}^{\prime} \text { versus } \sigma \\
{ }_{3}(3)\end{array}$ & $k=\frac{1+\sin \phi^{\prime}}{1-\sin \phi^{\prime}}$ & $\begin{array}{l}\text { Percent strain, } \\
\varepsilon(8)\end{array}$ & $\varepsilon(\%)=\left(\frac{u_{i}}{r_{0}}\right) \times 100=\left[0.2-0.25\left(\frac{p_{i}}{p_{0}}\right)\left(\frac{\sigma_{c m}}{p_{0}}\right)^{2.4\left(\frac{p_{i}}{p_{0}}\right)-2}\right)$ \\
\hline $\begin{array}{l}\text { Critical support } \\
\text { pressure } p_{c r} \\
\text { (4) }\end{array}$ & $P c r=\frac{2 p 0-\sigma c m}{1+k}$ & $\begin{array}{l}\text { Radius of } \\
\text { plastic zone } \\
\text { when } \mathrm{p}_{\mathrm{i}}=0 \\
\text { (9) }\end{array}$ & $\left(\frac{r p}{r 0}\right)=\left(1.25-0.625\left(\frac{p i}{p 0}\right)\left(\frac{\sigma c m}{p 0}\right)^{\left(\frac{p i}{p 0}\right)-0.57}\right)$ \\
\hline $\begin{array}{l}\text { Radial elastic } \\
\text { displacement } \\
\text { uie (5) }\end{array}$ & $u_{i e}=\frac{r_{0}(1+\vartheta)\left(p_{0}-p_{i}\right)}{E m}$ & & \\
\hline \multicolumn{4}{|c|}{$r p$, Plastic zone radius } \\
\hline \multicolumn{4}{|c|}{$u i$, Tunnel sidewall deformation } \\
\hline \multicolumn{4}{|c|}{ ro, Original tunnel radius in metres } \\
\hline \multicolumn{4}{|c|}{$p i$, Internal support pressure } \\
\hline \multicolumn{4}{|c|}{$p o$, In situ stress $=$ depth below surface $\cdot$ unit weight of rock mas $=p_{0}=\gamma * h$} \\
\hline \multicolumn{4}{|c|}{$\sigma \mathrm{cm}$, Rock mass strength $=2 \cos \varnothing /(1$ siøn $)$} \\
\hline \multicolumn{4}{|c|}{$E m$, Young's modulus or deformation modulus } \\
\hline \multicolumn{4}{|c|}{$v$, Poisson's ratio } \\
\hline \multicolumn{4}{|c|}{$\sigma_{1_{1}}$, Axial stress at which failure occurs } \\
\hline \multicolumn{4}{|c|}{$\sigma^{\prime}{ }_{3}{ }^{\prime}$ Confining stress } \\
\hline \multicolumn{4}{|c|}{$c^{\prime}$, Cohesive strength } \\
\hline$\varphi^{\prime} \mathrm{i} \varnothing^{\prime}$, Angle of fric & tion of the rock mass & & \\
\hline
\end{tabular}

tunnel convergence and the ratio of rock mass strength to in situ stress for unsupported tunnels [7] is given, and in Fig. 9, the approximate relationship between the strain and the degree of difficulty associated with tunnelling through squeezing rock

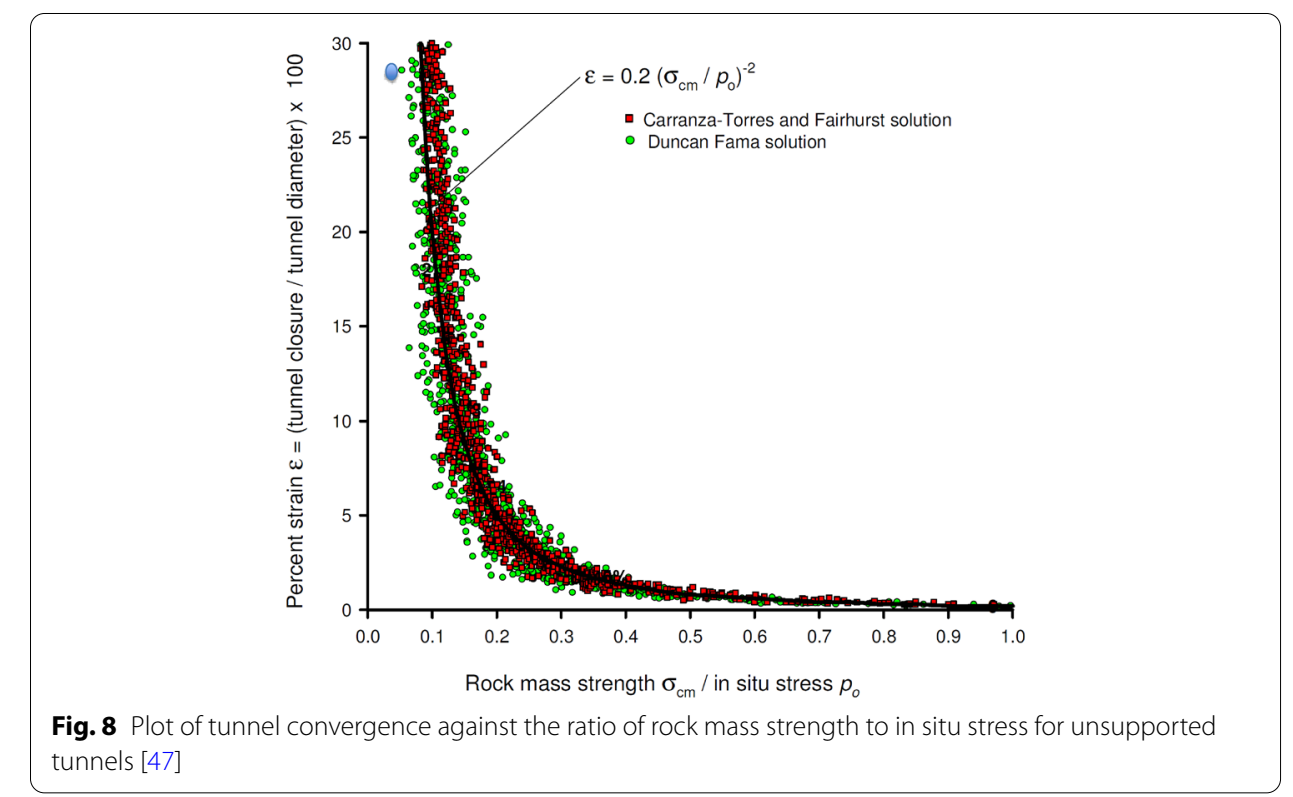




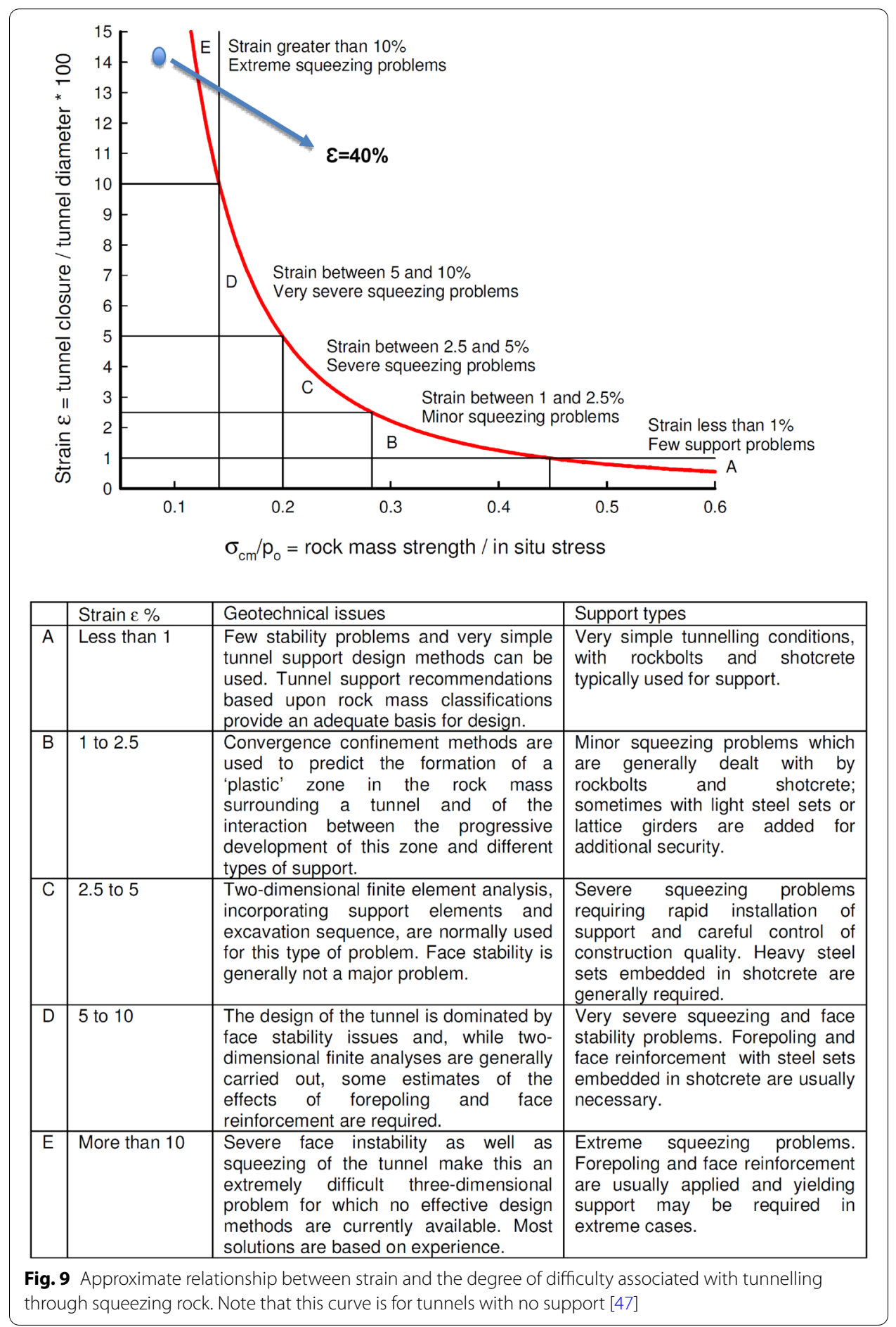

[7] is given. As seen from Figs. 8 and 9, the corresponding closure is not at an acceptable level; the tunnel should be closed at once, and this part of the tunnel falls within section E, as seen in Fig. 9. As mentioned above, face stability problems may emerge, so forepoling application and reinforcement of the tunnel face is required. If the strain 
levels exceed 5\%, tunnel face problems emerge, which reveals that providing stability of the tunnel face and implementing the forepoling method are mandatory [47].

\section{Rock support interaction analysis-characteristic curves}

There are many uncertainties in determining tunnel support systems. Primary uncertainties arise due to the limited number of studies and thus the lack of approaches produced based on these studies. Today, many researchers are working on determining ground reaction curves (GRCs), support reaction curves (SRCs), and longitudinal deformation profiles (LDPs) [44, 48-52]. Among these studies, optimization of the supports were provided for certain conditions and cases. Deformations that occurred before the installation of the first supports were investigated. In other words, the most appropriate support system and the most economical method were researched for a specific time period. Because not all of the in situ stresses $\left(\mathrm{P}_{0}\right)$ affect support systems, the main factor in identifying the most economical support system is estimating the $\mathrm{P}_{\mathrm{i}}$ value. There are also many observational approaches for estimating the loads affecting supports [37, 38]. Clearly, the basic approach depends upon the principle of accurately predicting the future load on the supports and application of the most economic support systems within the specific time period.

For each section of the tunnel, the ground characteristic curve, longitudinal displacement profile and SRC are plotted. For plotting the GRC, Eqs. 4 and 7 in Table 2 are used. In addition, the plastic zone radius is calculated according to Eq. 6 in Table 2. The Vlachopoulos and Diederichs [51] equations are used for plotting the longitudinal displacement profiles.

$$
u_{i}= \begin{cases}u_{i m}\left[\frac{u_{i f}}{u_{i m}} \cdot e^{x / r_{0}}\right], & x<0 \\ u_{i m}\left[\left(\frac{u_{i m}}{3}\right) e^{\left.-0.15\left(r_{p m} / r_{0}\right)\right],}\right. & x=0 \\ u_{i m}\left[1-\left(1-\frac{u_{i f}}{u_{i m}}\right) \cdot e^{\left(-3 x / r_{0}\right) /\left(2 r_{p m} / r_{0}\right)}\right], & x>0\end{cases}
$$

Here, $\mathrm{u}_{\mathrm{if}}$ is the deformation in the tunnel face, and $\mathrm{u}_{\mathrm{im}}$ is the maximum displacement, which occurs at the $r_{p m}$ scale. While determining the tunnel support systems, the equations given in Table 3 are employed $[44,53]$. Equations are given under the condition of a hydrostatic background stress state for steel shoring, shotcrete lining and bolts in a circular tunnel. The summary table of the support system selected in both parts of the tunnel is given in Table 4 .

For the tunnel section, the ground reaction curve (Fig. 10), longitudinal displacement profile (Fig. 11) and SRC (Fig. 12) were plotted. In addition, the tunnel support system pressures and stiffness values are given in Table 5.

The parameters used in the calculations are as follows: $\mathrm{r}_{\mathrm{pm}} / \mathrm{r}_{0}=2.83$, tunnel face displacement $u_{i f}=0.04 \mathrm{~m}$, maximum face displacement $u_{\mathrm{im}}=0.184 \mathrm{~m}$, and face displacement $/$ max displacement $u_{i f} / u_{i m}=0.21$. Tunnel support systems should be established immediately after excavation when tunnels pass through very weak ground conditions. In this case, $4 \mathrm{~cm}$ of deformation occurs in the tunnel face; if the support system was constructed $1 \mathrm{~m}$ behind the tunnel face, $5 \mathrm{~cm}$ of deformation would occur (Fig. 11). In Fig. 10, the support pressures required to stabilize the deformation at the level of $5 \mathrm{~cm}$ are calculated as $0.03 \mathrm{MPa}$. A comparison of Fig. 10 and clearly shows that the 
Table 3 Support capacity equations $[44,53]$

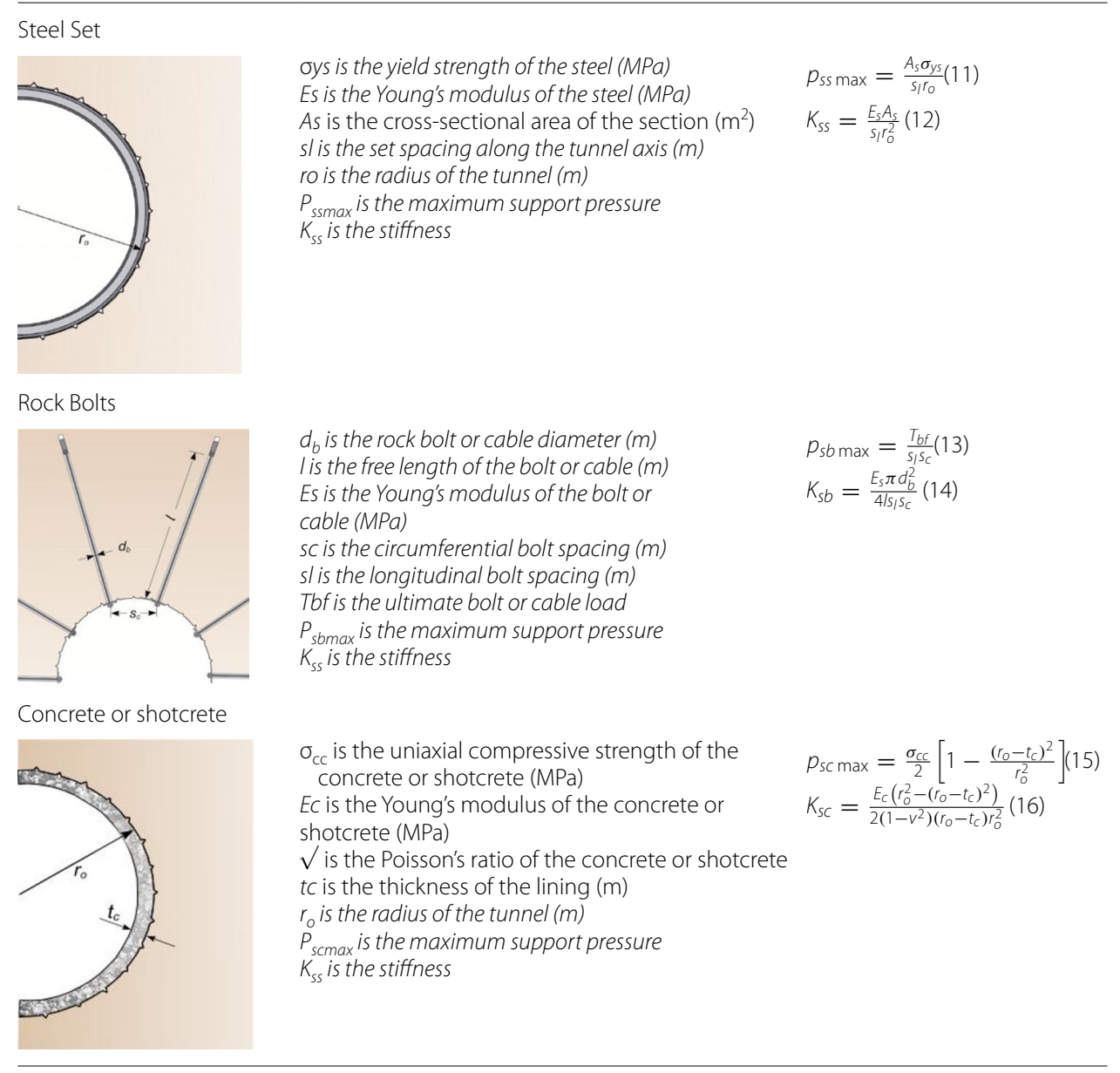

Table 4 Support properties between the portal and km: $210+150$

\begin{tabular}{ll}
\hline Shotcrete, C20/25 & $40 \mathrm{~cm}$ \\
Steel rib & 1200 \\
Rock bolts & $6-8 \mathrm{~m}$, self-drilling bolt, \\
& $\mathrm{d}=32 \mathrm{~mm}, \mathrm{P}_{\text {ult }}=280 \mathrm{kN}$ \\
Forepoling & $12 \mathrm{~m}, 3.5 \mathrm{or} 4^{\prime \prime}$ with $6 \mathrm{~m}$ overlap \\
Excavation step (m) & $1 / 2 / 4$ \\
Top heading/bench/invert & 2 layer \\
wire mesh, Q221/221 & $10 \mathrm{~cm}$ shotcrete/1 layer wire mesh \\
Face support & 12 face bolts \\
\end{tabular}

deformation, which was observed immediately after the tunnel excavations, proceeded very rapidly due to the extremely weak ground conditions. The plastic zone radius exhibits a sudden increase with a plastic zone radius of $10.5-18 \mathrm{~cm}$, whereas for the condition with the support system installed $1 \mathrm{~m}$ behind the tunnel face (in terms of deformation), all the overburden is in the plastic zone area. Slippage of the tunnel face and discharges from the tunnel ceiling are also possible because of the cohesionless ground conditions. 


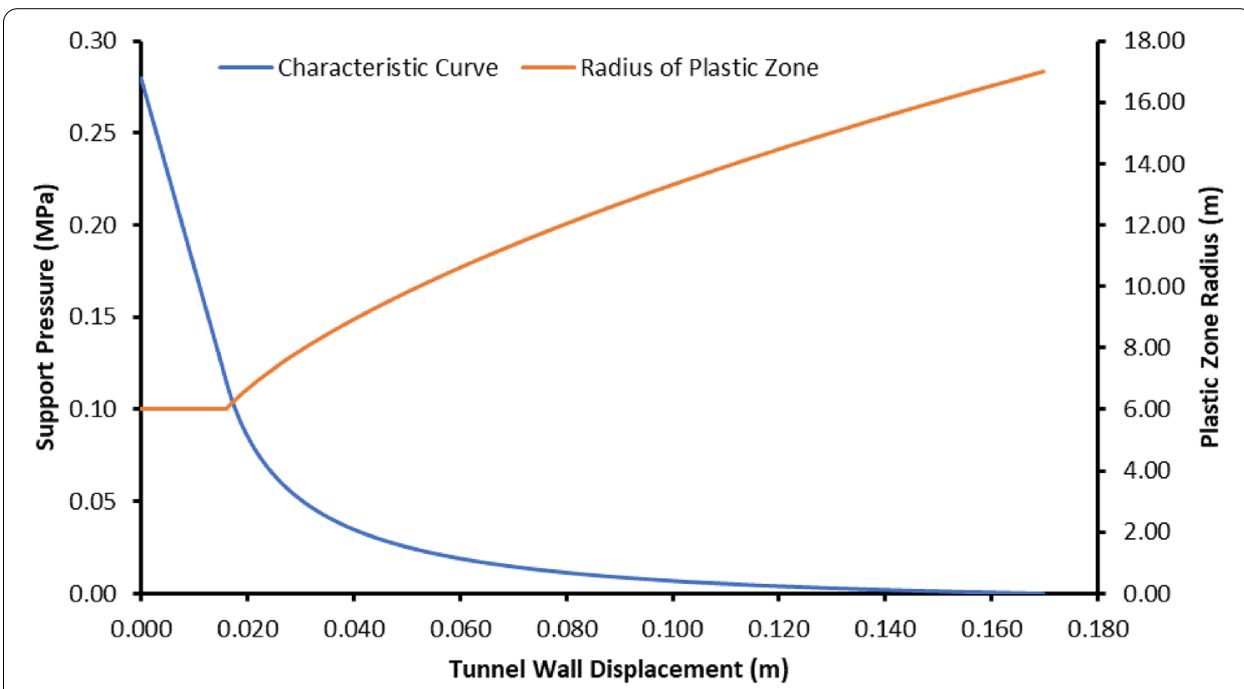

Fig. 10 Characteristic curve for the studied section of the T4 tunnel

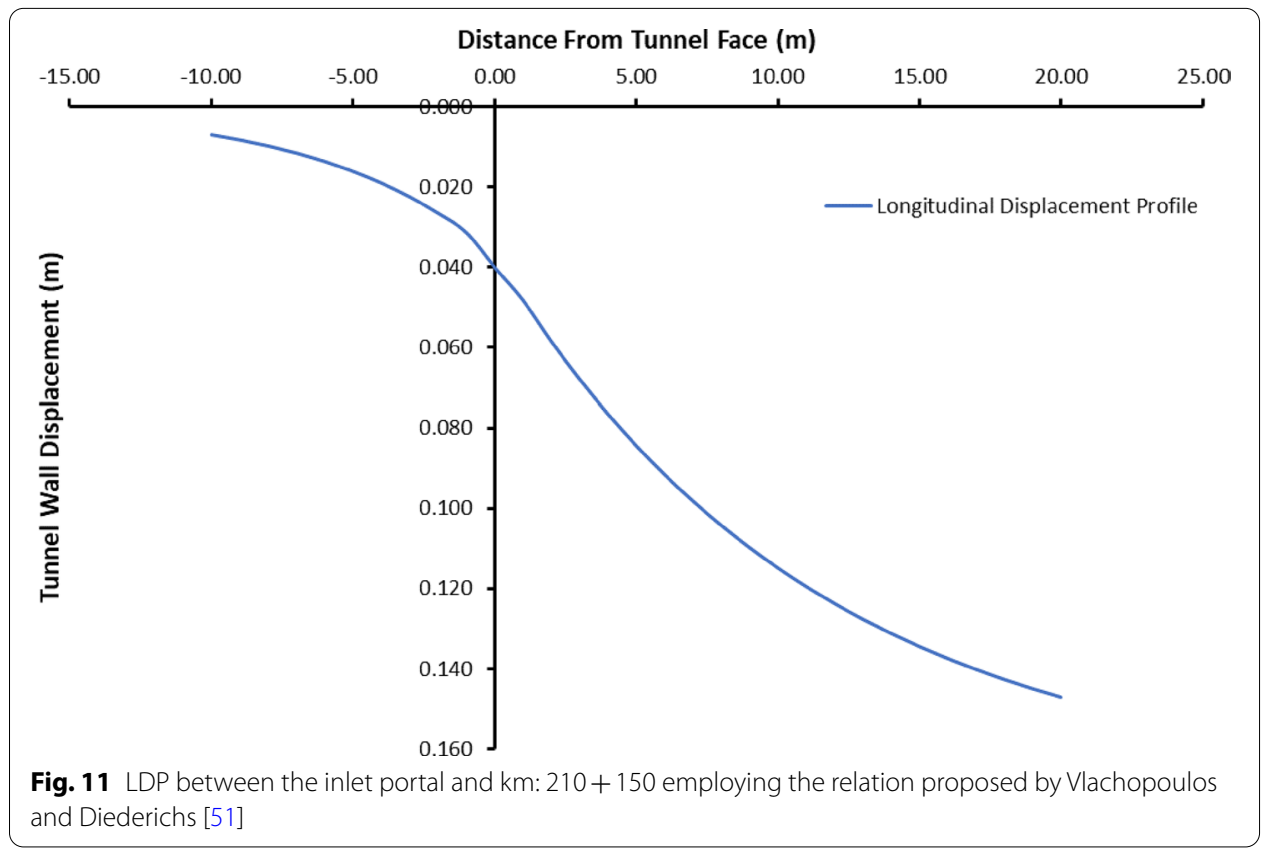

For this reason, to increase the strength parameters of the ground (elastic modulus, cohesion and internal friction angle) in the tunnel ceiling and tunnel face, umbrellas are also required for the tunnel ceiling. In addition, the GRCs and SRCs with selected support elements (shotcrete, steel rib and bolts) are given in Fig. 12. In summary, tunnel support systems should be completed immediately to avoid deformation inside the tunnel. Otherwise, deformation develops very rapidly and can result in tunnel failure. 


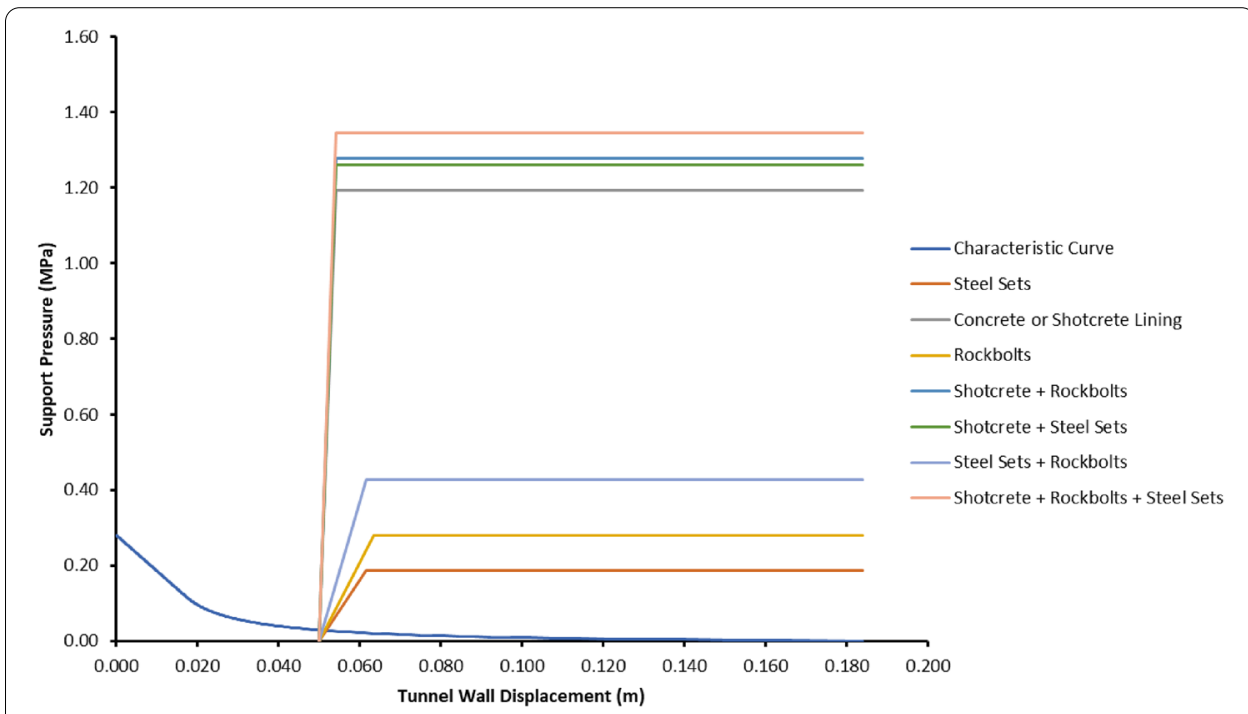

Fig. 12 GRCs and SRCs between the entrance portal and km: $210+150$

Table 5 Support pressure between entrance portal and km: $210+150$

\begin{tabular}{llcl}
\hline & $p_{\text {scmax }}(\mathrm{MPa})$ & $K_{\text {sc }}(\mathrm{MPa} / \mathrm{m})$ & $u_{\text {icmax }}(\mathrm{m})$ \\
\hline Shotcrete $(\mathrm{ds}=40 \mathrm{~cm})$ & 1.12 & 290.280 & 0.0541 \\
Steel rib $(\mathrm{I} 200)$ & 0.18 & 16.36 & 0.061 \\
Rock bolts & 0.28 & 20.810 & 0.063 \\
\hline
\end{tabular}

\section{D numerical analyses}

3D numerical analyses are commonly used to analyse deformation and the performance of support systems $[26,27,54]$. 3D numerical analyses are performed to investigate not only tunnelling but also other construction processes [55-60]. Excavation for the T4 tunnel was initiated by a tunnel support system application. However, due to severe tunnel deformation and critical settlement, the excavation was interrupted. By adequately revising the support system, the tunnel excavation continued successfully. The main reason for the failure of the support is the implementation of Store-Norfers (SN) bolts and inadequate forepoling installation at the tunnel crown, together with the absence of support on the tunnel face. SN bolts are installed by first drilling a hole, grouting through it, and then mounting the bolt. When installing bolts through silty, sandy, and gravelly soils, it is possible that the holes fill with their constituent natural materials instead of the design grout mixture. In addition, due to the action of gravity, the grout on the tunnel ceiling may not be affixed, leading to insufficient grouting. Eventually, this may cause a malfunction of the bolts. If too short $(\mathrm{L}=4 \mathrm{~m})$, the $1.5^{\prime}$ diameter bolts proposed to stabilize the tunnel crown stability will be ineffective. As a consequence, flow and discharges occurred from the tunnel ceiling. To ensure stability of the tunnel face, fibre bolts and shotcrete should be applied.

As explained above, the gravel in the silty-clayey matrix units exhibits flow characteristics at the shallow tunnel location, causing issues for tunnel excavation. Accordingly, by 


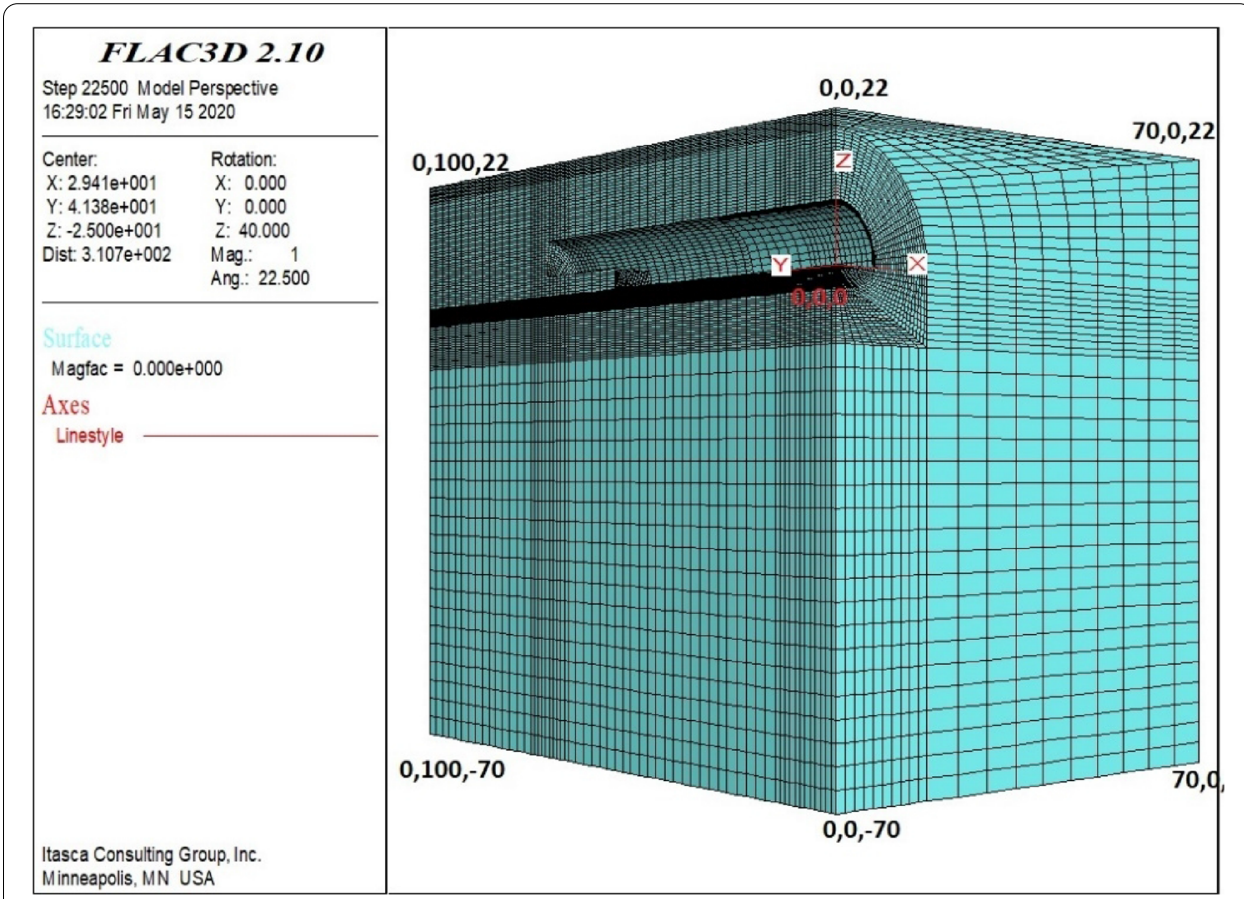

Fig. 13 FLAC3D model of the tunnel between the inlet portal and km: $210+150$

Table 6 Parameters used for modelling the shotcrete and interior lining concrete

\begin{tabular}{lccc}
\hline Element & Ei (GPa) & $\sqrt{ }$ & $\begin{array}{l}\Upsilon(\mathrm{kg} / \\
\left.\mathrm{m}^{3}\right)\end{array}$ \\
\hline Shotcrete & 25 & 0.25 & 2500 \\
Inner concrete lining & 30 & 0.25 & 2500 \\
\hline
\end{tabular}

taking these flow characteristics into account to determine an adequate support system, analyses were performed. The umbrella arch method, as a pre-reinforcement approach of tunnels in complex geological conditions, is widely used to maintain tunnel stability $[32,61]$.

The model to be used for the following 3D analyses is shown in Fig. 13. According to the symmetric conditions, half of the tunnel is modelled (Fig. 3). The centre of the tunnel is assumed to have the coordinates of $(0,0,0)$. The boundary conditions selected are 5 times the diameter of the tunnel. The bottom of the model is $70 \mathrm{~m}$ long in the $\mathrm{z}$ direction, $70 \mathrm{~m}$ in the $\mathrm{x}$ direction and $100 \mathrm{~m}$ in the $\mathrm{y}$ direction (excavation face).

First, analyses were carried out for the case in which no bolts were installed at the tunnel face, and the resulting displacements were examined. The tunnel numerical analyses were investigated in the sandy gravel units between the entrance portal and $\mathrm{km}$ : $210+150$, which were considered low-cohesion units. In addition, since the cover thickness of the first section is shallow, analyses were performed for the 12-15 m section. The support systems were modelled with FLAC3D. In the model, a vertical plane of symmetry was assumed along the centre of the tunnel, so half of the tunnel is modelled. The 
Table 7 Parameters used for modelling the cable bolts

\begin{tabular}{lllll}
\hline Cable modulus (GPa) & Cable modulus $\left(\mathrm{m}^{2}\right)$ & $\begin{array}{l}\text { Cable ultimate tensile } \\
\text { capacity }(\mathrm{kN})\end{array}$ & $\begin{array}{l}\text { Grout bond stiffness } \\
(\mathrm{N} / \mathrm{m} / \mathrm{m})\end{array}$ & $\begin{array}{l}\text { Grout cohesive } \\
\text { strength }(\mathrm{N} / \mathrm{m})\end{array}$ \\
\hline 45 & $1.57 \times 10^{-3}$ & 250 & $1.75 \times 10^{7}$ & $2.0 \times 10^{5}$ \\
\hline
\end{tabular}

Table 8 Parameters used for modelling the umbrellas

\begin{tabular}{lllll}
\hline Diameter of pipe $(\mathrm{m})$ & Thickness of pipe $(\mathrm{m})$ & $U$ & $E(G P a)$ & Yield (N) \\
\hline 0.114 & 0.0065 & 0.3 & 200 & 200,000 \\
\hline
\end{tabular}

Table 9 Ground parameters for units reinforced with rock bolts (entrance portal to km: 210+150)

\begin{tabular}{ll}
\hline Bolt drilling diameter & 0.076 \\
\hline Distance between two bolts & $1.00 \mathrm{~m}$ \\
$\mathrm{q}_{\mathrm{u}}$ & $10.0 \mathrm{MPa}$ \\
$\mathrm{a}_{\mathrm{r}}$ & 0.00453416 \\
$\mathrm{E}_{\text {soil }}$ & $80,000 \mathrm{kPa}$ \\
$\varphi_{\text {soil }}$ & $35^{\circ}$ \\
$\mathrm{C}_{\text {soil }}$ & $5 \mathrm{kPa}$ \\
$C_{\text {jg }}$ & $10.0 \mathrm{MPa}$ \\
$\mathrm{E}_{\mathrm{jg}}$ & $1,000,000 \mathrm{kPa}$ \\
$C_{\text {comp }}$ & $50 \mathrm{kPa}$ \\
$\varphi_{\text {comp }}$ & $0^{\circ}$ \\
$\mathrm{E}_{\text {comp }}$ & $84,171 \mathrm{kPa}$ \\
\hline
\end{tabular}

total length of the tunnel is $100 \mathrm{~m}$, the overburden is nearly $15 \mathrm{~m}$, and the floor of the tunnel is located $22 \mathrm{~m}$ below the ground surface (Fig. 13).

The shotcrete was described with a shell element to the model. The inner concrete lining at the back of the tunnel was also defined as a different zone of the model. The soil nails applied at the tunnel were are defined as cable bolts. Tables 6 and 7 show the parameters used for modelling the shotcrete, inner concrete lining and cable bolts.

Umbrellas are described in the model with 'pile' elements. The numerical and analytical solutions during the description stage of umbrellas in the model refer to the work of Oke et al. [62-66], who stated that it is appropriate to define umbrellas as a pile element in FLAC3D. Table 8 summarizes the parameters used for modelling the umbrellas.

In the model, the cohesion and deformation modulus of the ground parameters around the tunnel were defined with the rock bolts in the tunnel. In other words, the ground parameters of the bolts and the soil units were estimated after the grouting procedure was completed. In this approach, the ground and rock bolts around the tunnel are represented as a single unit. In a sense, the reinforcement of the soil units around the tunnel were simulated by assigning new soil parameters (Table 9).

In the 3D analysis, the top heading, bench and invert were modelled. In this work, the round lengths for the top heading, bench and invert sections were taken to be 1 , 2 and $4 \mathrm{~m}$, respectively, located at $100 \mathrm{~m}$ in the $\mathrm{Y}$ direction, $70 \mathrm{~m}$ in the $\mathrm{X}$ direction 

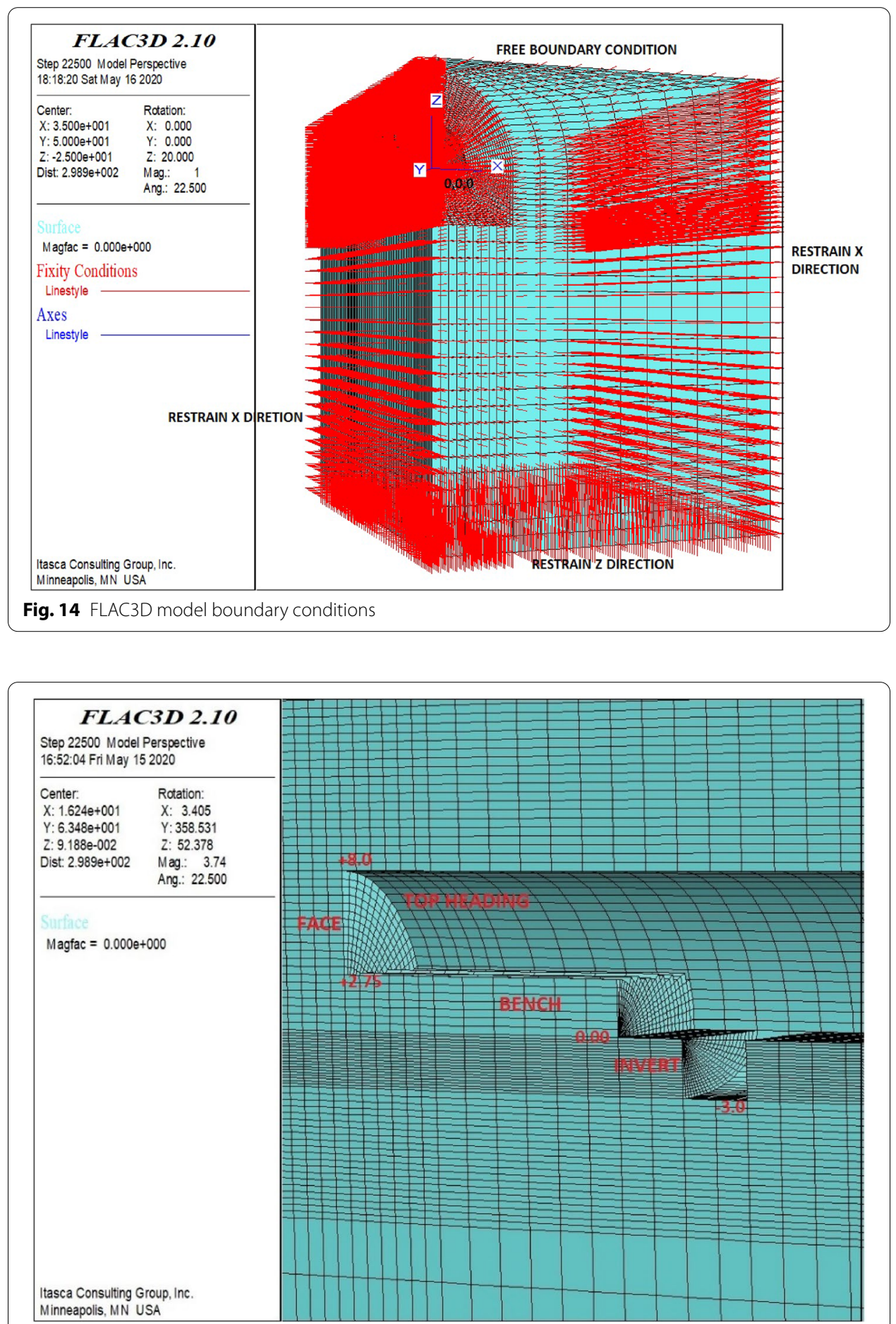

Fig. 15 Top heading, bench and invert levels

and $-70 \mathrm{~m}$ in the $\mathrm{Z}$ direction in the first modelling stage. The model is considered symmetrical. In the model, the loading condition is selected as the gravity method. The model is fixed at $0-100 \mathrm{~m}$ in the y direction, $-70 \mathrm{~m}$ in the $\mathrm{Z}$ direction, and $0-70 \mathrm{~m}$ in the $\mathrm{x}$ direction (Fig. 14). Additionally, the Mohr-Coulomb failure criterion 


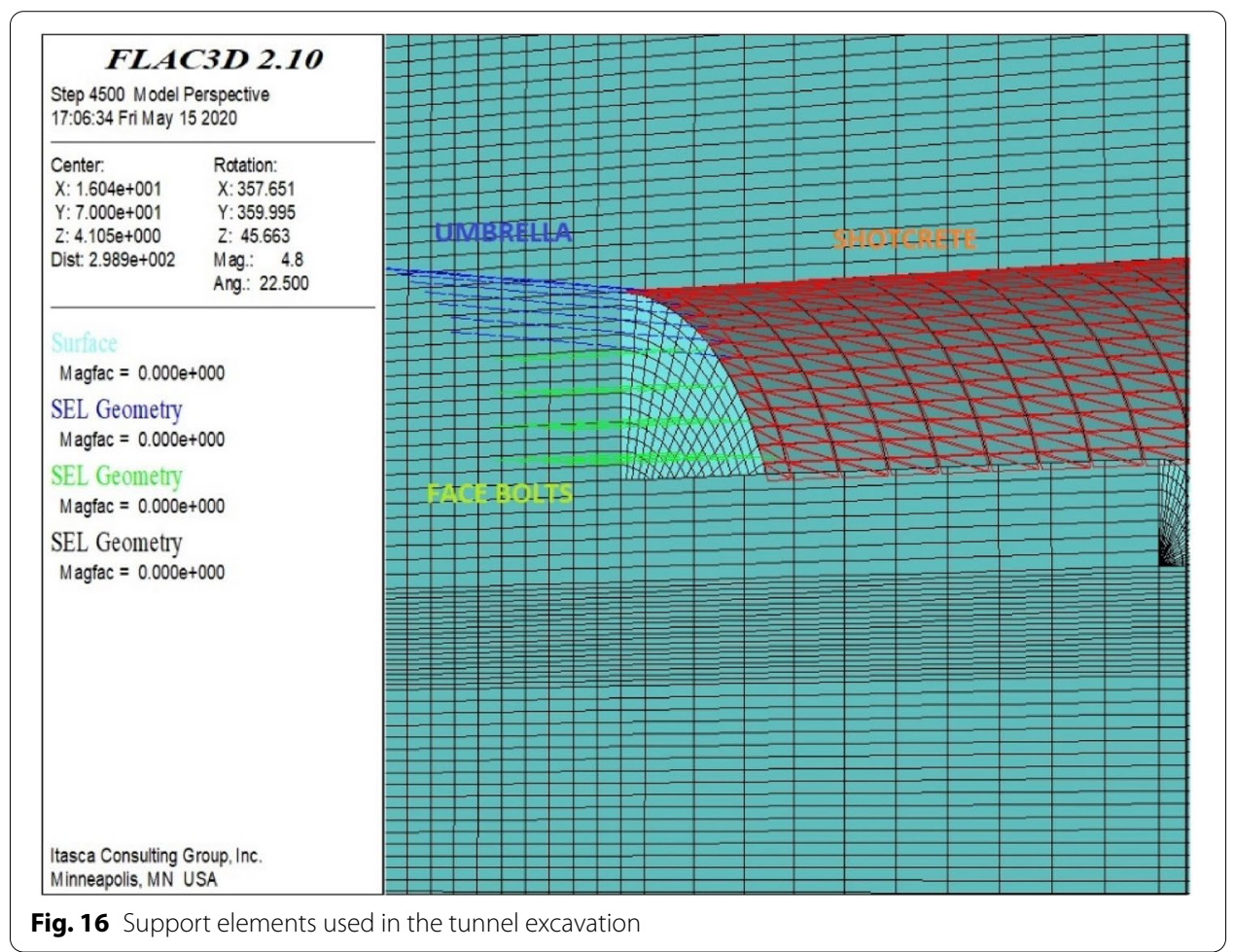

Table 10 Bulk, shear and deformation moduli

\begin{tabular}{llll}
\hline $\begin{array}{l}\text { E } \\
\text { (Deformation Modulus, MPa) }\end{array}$ & $\begin{array}{l}\sqrt{ } \\
\text { (Poisson's Ratio) }\end{array}$ & $\begin{array}{l}\text { K (Bulk Modulus, } \\
\text { MPa) }\end{array}$ & $\begin{array}{l}\text { G (Shear Modulus, } \\
\text { MPa) }\end{array}$ \\
\hline 80 & 0.3 & 66 & 30 \\
\hline
\end{tabular}

is selected for the model. Tunnel excavation started at the top heading from $60 \mathrm{~m}$. The top heading section was null until an advance of $60 \mathrm{~m}$, while the bench section was null until $40 \mathrm{~m}$, and the invert section was null until $36 \mathrm{~m}$. The support system of this section was installed and entered into the model; additionally, it was assumed that the inner lining was constructed for the first $24 \mathrm{~m}$ section of the tunnel. Therefore, the required distance was secured for the top heading, bench, invert and inner lining (Fig. 15). After this stage, excavation steps proceeded in $1 \mathrm{~m}$ round lengths in the top heading. By first excavating the top heading for $2 \mathrm{~m}$, then excavating the bench section for $4 \mathrm{~m}$ and finally completing the excavation of the invert section, the excavation stages were completed. The excavation process was continued in this way, and finally, a total of $8 \mathrm{~m}$ of excavation was completed in the top heading, bench and invert sections. Between the entrance section and km: $210+150$, in the tunnel face, $12 \mathrm{~m}$ long and $4.0^{\prime \prime}$ umbrellas were applied in the ceiling section, and $12 \mathrm{~m}$ long face soil nails accompanied by $40 \mathrm{~cm}$ shotcrete were installed to ensure the face stability. Between the entrance section and $\mathrm{km}: 210+150,9 \mathrm{~m}$ long and 4.0" umbrellas were applied in the ceiling section, and $9 \mathrm{~m}$ long face soil nails accompanied by $40 \mathrm{~cm}$ shotcrete were installed to ensure face stability. The face soil nails and umbrella applications are represented in Fig. 16. 
FLAC3D software uses the bulk modulus, $\mathrm{K}$ and shear modulus to represent the ground parameters in the model. These values are related to the deformation modulus (E) and Poisson's ratio (v) [40] and are presented in Table 10.

Bulk Modulus: $v$

$$
K=\frac{E}{3(1-2 v)}
$$

Shear Modulus

$$
G=\frac{E}{2(1+v)}
$$

In the analysis performed on this section of the T4 tunnel, the stresses in the model were estimated considering the gravity method, and the surface stresses remained constant. First, the deformation of the tunnel ceiling and tunnel face was examined. In the absence of face bolts and umbrellas on the tunnel ceiling and face, settlement occurred in the $\mathrm{Z}$ direction as the tunnel excavation continued to the surface, reaching $1.3 \mathrm{~m}$ at the crown (Fig. 17).

In the tunnel face, it was observed that the deformation in the $\mathrm{Y}$ direction reached $70 \mathrm{~cm}$ (Fig. 18); in other words, a collapse occurred in the tunnel.

When the total displacement in the tunnel face was examined, it was observed that the collapse clearly reaches the surface (Fig. 19).

With the application of the soil nails and umbrella in the tunnel face and tunnel ceiling, the displacement occurring on the tunnel ceiling reflected a convergence of $2 \mathrm{~cm}$ towards the tunnel in the horizontal direction (Figs. 20 and 21). In addition, in the $\mathrm{Z}$

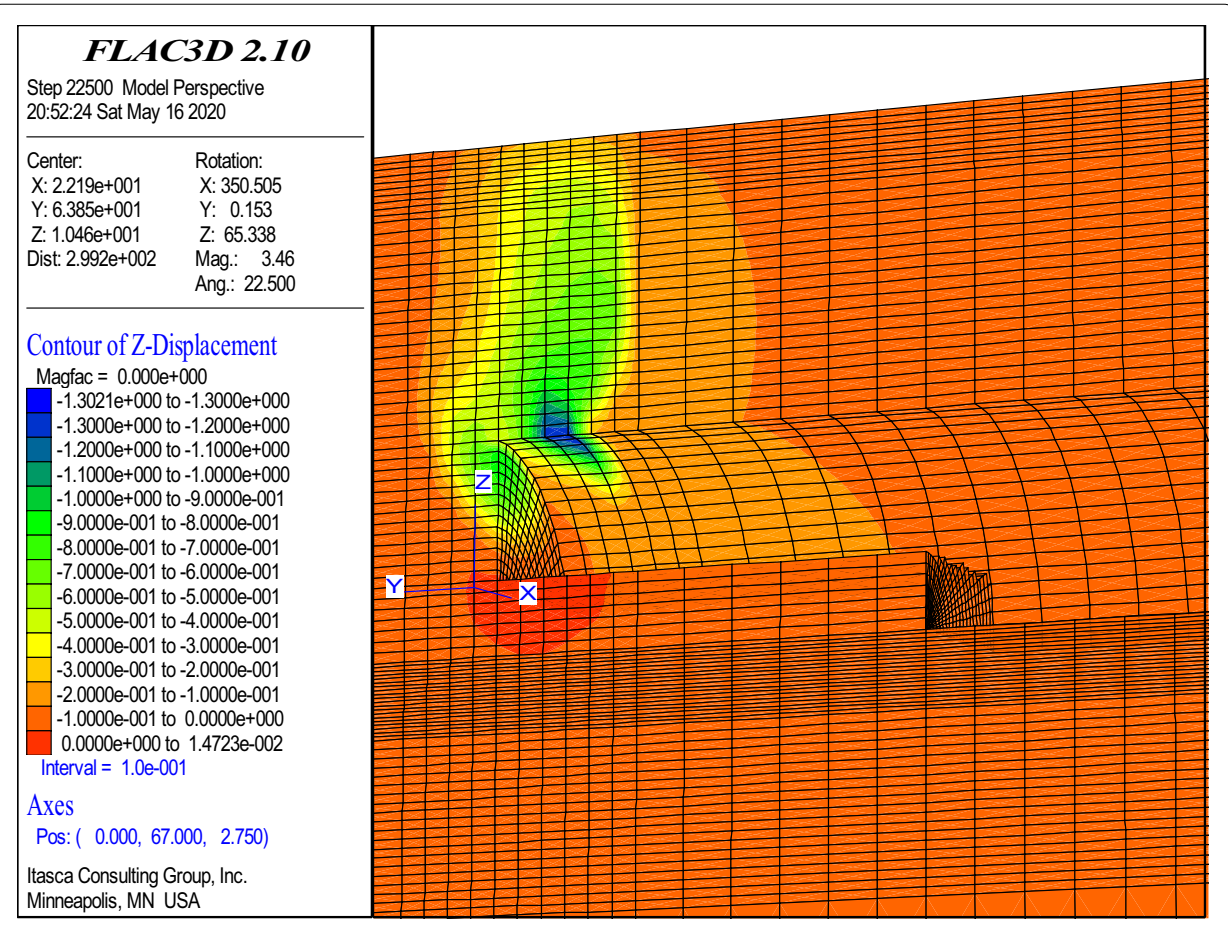

Fig. 17 Displacement in Z direction 


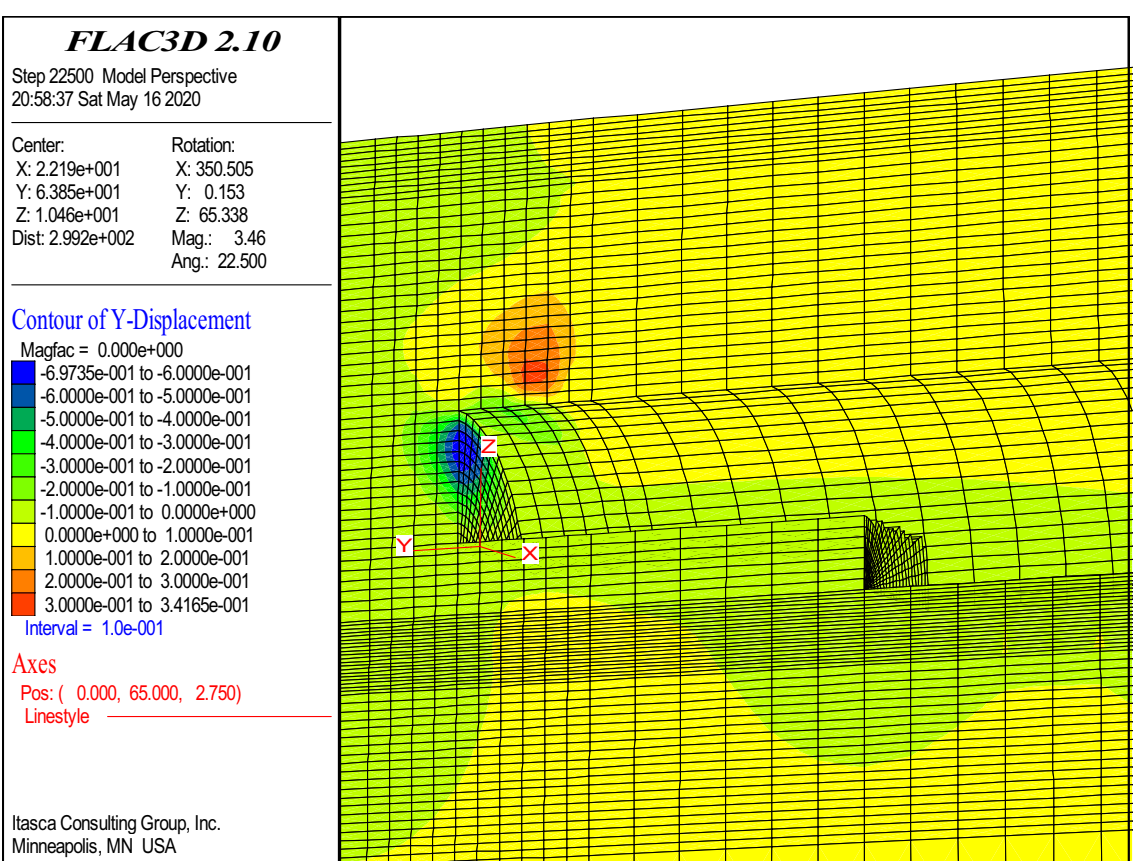

Fig. 18 Displacement in the $Y$ direction

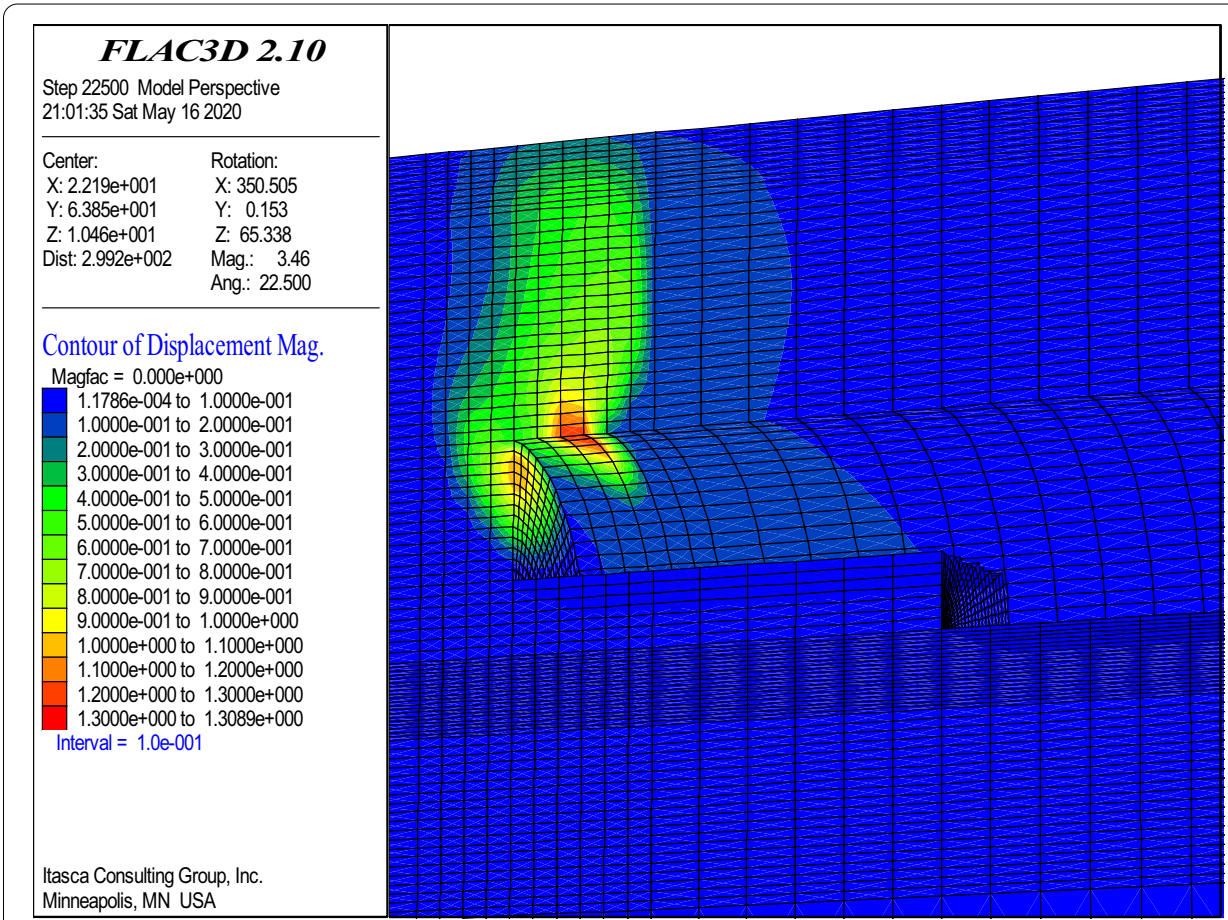

Fig. 19 Total displacement developed at the studied section 


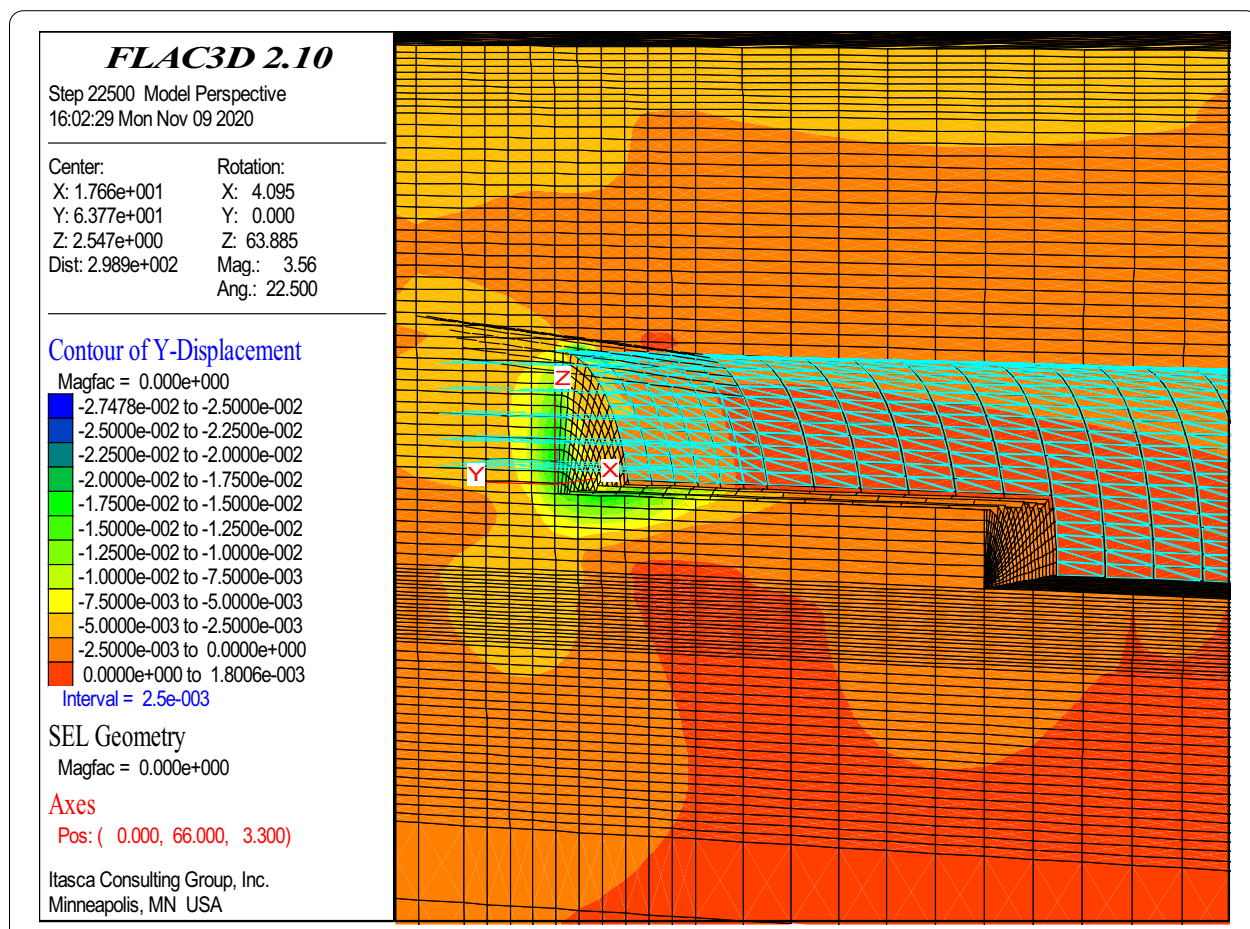

Fig. 20 Horizontal displacement in the $Y$ direction

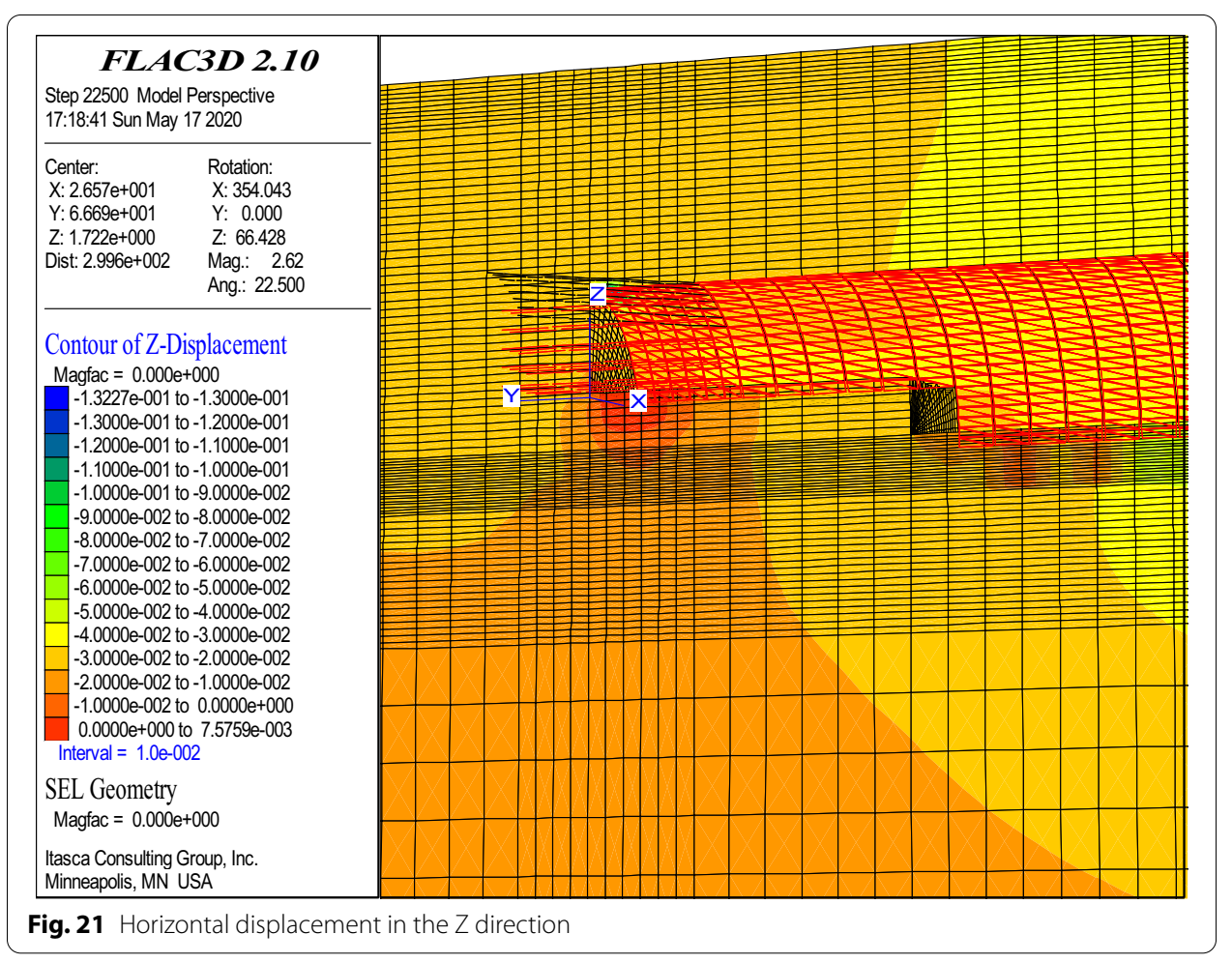




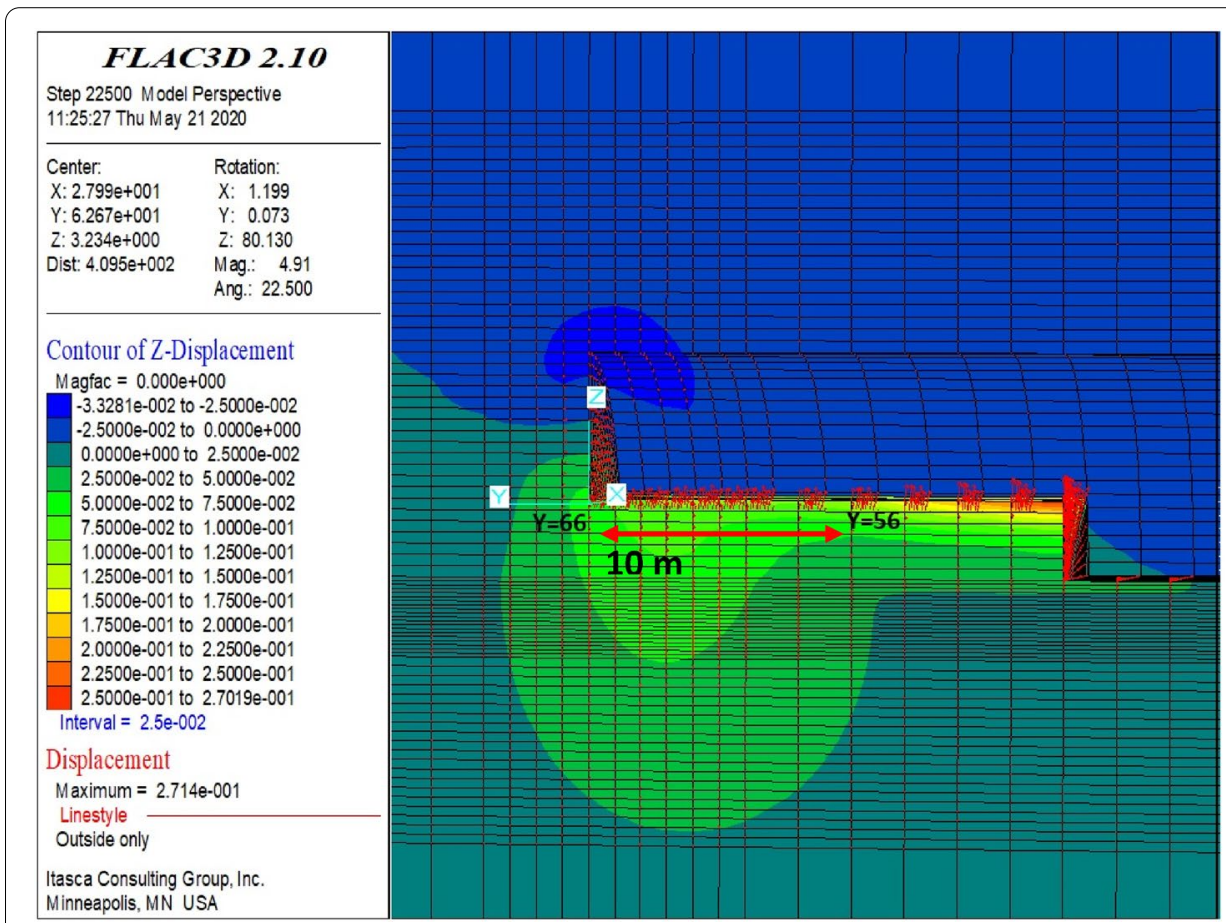

Fig. 22 Swelling at the top heading section in the Z direction (without umbrella and forepoling)

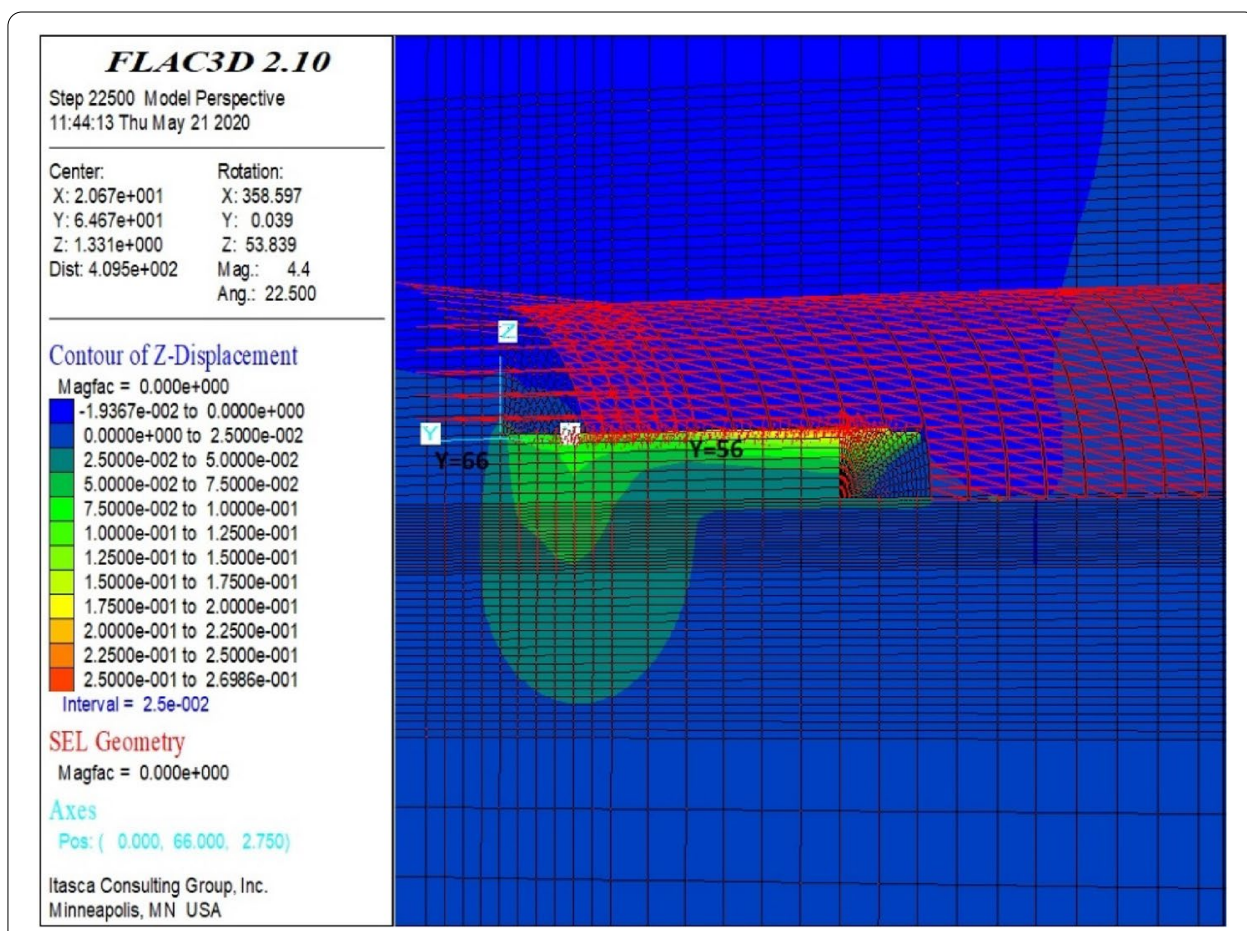

Fig. 23 Swelling at the top heading section in the Z direction (with umbrella and forepoling) 
direction, vertical settlement occurred at approximately $10 \mathrm{~cm}$, and the tunnel remained stable. Moreover, the surface displacement is approximately $2 \mathrm{~cm}$ at the tunnel face, while it is approximately $3 \mathrm{~cm}$ at the section where ring closure is realized.

When the top heading and bench distances were analysed with FLAC3D, it was observed that between the top heading and bench section, an approximately $10 \mathrm{~m}$ distance, approximately $10 \mathrm{~cm}$ of swelling takes place along the $\mathrm{Z}$ direction, which gradually increases after this point. In other words, the requirement of an intermediate temporary invert arises in the top heading section; additionally, the distance between the top heading and bench excavations should be secured at approximately $10 \mathrm{~m}$ (Figs. 22 and 23). As shown in Fig. 22 and Fig. 23, the deformations in the $\mathrm{Z}$ direction increase; hence, in this area, the intermediate invert is necessary for face and tunnel stability.

\section{Discussion and conclusions}

The T4 tunnel with a shallow overburden thickness was excavated through extremely weak (flowing) ground. For this type of ground condition, the risk of instability of the tunnel face and serious material flows from the tunnel ceiling is significant. Therefore, unsupported tunnel excavation should not be initiated, regardless of whether necessary measures are taken at the tunnel face and ceiling. In the present study, analytical solutions for tunnel support systems and corresponding 3D numerical analyses were performed, and the results obtained from these two methodologies were compared. Consequently, the conclusions obtained from the study can be drawn as follows:

SN bolts should not be applied through sandy and silty units since the holes drilled for placing those bolts are destroyed due to flowing soil features and lead to impractical conditions for grouting. Therefore, for this type of soil, a self-drilling bolt must be used. Then, grouting can be applied through the bolt openings, which will facilitate consolidation of the grout material around the tunnel. With successful grouting, no gaps will exist around the tunnel. This technique will help achieve the arch effect of the load distribution around the tunnel ceiling.

For tunnels with silty, sandy, and gravelly units, the tunnel stability is directly associated with the application of bolts and forepoling at the tunnel ceiling. In shallow tunnels where the soil characteristics are defined as flowing due to cohesionless features, potential face-flowing during excavation work may result in discharges at the tunnel ceiling, in turn increasing the risks of collapse inside the tunnel. This risk can extend to the ground surface and result in high re-excavation costs. Therefore, umbrellas (forepoling) at the tunnel ceiling should be at least 9-12 m long, and overlaps should be designed with a minimum ratio of $1 / 3$. Additionally, high-pressure grouting should be maintained through the forepoling system until refusal is reached. This type of application will ensure face stability of the tunnels during excavation and will be useful in preventing potential collapses at the tunnel ceiling. For the tunnel face, a continuous installation of fibre-type rock bolts is required for establishing face stability, without which a possible sliding on the tunnel face would adversely affect the tunnel support systems.

The top heading, bench, and invert need to be close to each other. The distance between the top heading and bench can be a maximum of $20 \mathrm{~m}$ in length, whereas the distance between a bench and an invert can be as short as $10 \mathrm{~m}$. Additionally, the 
excavation ring must be closed as quickly as possible. In the top heading, an intermediate invert is necessary after face excavation for face and tunnel stability.

The stability of tunnel faces should be progressively sustained through rock bolts and grouting applications. Additionally, discharge at tunnel faces should be prevented by using shotcrete. At the ceiling of the T4 tunnel, which was excavated through flowing material, the forepoling method had to be implemented to stabilize the ceiling sections; otherwise, discharge at the ceiling, a characteristic of shallow tunnels, may greatly increase the risk of collapse. To examine both the face stability and ceiling stability of the tunnel excavated through non-cohesive and low-cohesion flowing soils, it is necessary to perform 3D analyses. Through these 3D analyses, the features of the required umbrellas, such as their length, type and diameter, can be specified, and the size of the face soil nails can be determined.

According to the analytical solutions, if the support systems are not applied immediately after tunnel excavation, deformation develops very rapidly, and the plastic zone reaches the surface. Similarly, 3D analysis indicates that the deformation reaches $1.3 \mathrm{~m}$ and the plastic zone develops to the surface when there are no face bolts or forepolings.

Due to some assumptions considered in the analytical solutions, the calculated deformation results are greater than those of the 3D numerical analyses. Because all the support elements can be described in the 3D model, more optimistic results were obtained from the 3D numerical analyses.

Acknowledgements

The authors thank the General Directorate of TCDD (Turkish State Railway) and Fugro Sial Co. for their support.

Authors' contributions

All authors read and approved the final manuscript.

\section{Declarations}

Competing interests

There are no conflicts of interest to report.

Author details

${ }^{1}$ Fugro Sial Geosciences Consulting Engineering Ltd, Cankaya, 06680 Ankara, Turkey. ${ }^{2}$ Department of Geological Engineering, Hacettepe University, Beytepe, 06800 Ankara, Turkey.

Received: 28 August 2020 Accepted: 11 February 2021

Published online: 04 April 2021

\section{References}

1. Zhang Z, Li H, Yang H, Wang B (2018) Failure modes and face instability of shallow tunnels under soft grounds. Int J Damage Mech 28(4):566-589

2. Assis A (2013) Urban tunnelling constraints and challenges, master course on tunnels and underground space, $\mathrm{pp}$ 43

3. Gupta SK (2018) Foreseen challenges in underground tunneling for Mumbai metro line 3, MMRC, pp 48

4. Hoek E (2012) Alternative ground control strategies in underground construction, practices and trends for financing and contracting tunnels and underground works

5. Hoek E (2000) Big tunnels in bad rock, 2000 Terzaghi lecture. ASCE J Geotech Geoenviron Eng 127(9):726-740

6. Hoek E, Guevara R (2009) Overcoming squeezing in the Yacambú-Quibor tunnel. Venezuela Rock Mech Rock Eng 42(2):389-418

7. Rubiralta N, Hernandez A, Ergut S, Shaban A (2019) Logistic challenges for TBM operation during Sofia Metro Line 3 extension, Tunnels and Underground Cities: Engineering and Innovation meet Archaeology, Architecture and Art Peila, Viggiani \& Celestino (Eds), Taylor \& Francis Group, London, ISBN 978-1-138-38865-9

8. Heslop P (2018) Bored tunnelling in urban environments design and construction issues—what can be a problem and why, Amberg Engineering, Tunnelling and Underground Space Technical Division, The Institution of Engineers, Malaysia 
9. Li Z, Wang L, Feng B, Xiao J, Zhang Q, Li L, Liang J (2020) Comprehensive collapse investigation and treatment: an engineering case from Qingdao expressway tunnel. J Clean Prod 270:121879

10. Astore G, Pradella G (2009) The new Anatolian Metro of Istanbul, Tunnelling in urban area, Zurich

11. Taromi M, Eftekhari A, Hamidi JK, Eghbali A (2018) Tunnel designing and construction process in difficult ground conditions using Controlled Deformations (ADECO) approach; a case study. Int J Mining Geo Eng 52-2:149-160

12. Antony R, Louis C, Mark W, Franky FK (2019) The integrated delivery of a major urban tunnelling project: Hong Kong West Drainage Tunnel. https://www.dsd.gov.hk/EN/Files/Technical_Manual/technical_papers. Accessed on Dec 20 2019

13. Kovari K, Ramoni M (2004) Urban tunnelling in soft ground using TBM's, International Congress on Mechanized Tunnelling: Challenging Case Histories Politecnico di Torino, Italy, 16-19 November.

14. Rabcewicz LV (1964a) The New Austrian Tunnelling Method, Part One, Water Power, pp 453-457

15. Rabcewicz LV (1964b) The New Austrian Tunnelling Method, Part Two, Water Power, pp 511-515

16. Rabcewicz LV (1965) The New Austrian Tunnelling Method, Part Three, Water Power, pp 19-24

17. Whittaker BN, Frith RC (1990) Tunnelling design stability and construction, The Institution of Mining and Metallurgy, England, 460

18. Goricki A, Rachaniotis N, Hoek E, Marinos P, Tsotsos, S, Schubert W (2006) Support Decision Criteria for Tunnels in Fault Zones, Proceedings of the 55th Geomechanics Colloquium, Salsberg Published in Felsbau, 24/5, 200

19. Sulem J. Tran Manh J (2014) Tunnels in squeezing ground: Modelling of time-dependent anisotropic deformation, MIR 2014-XV Ciclo di Conferenze di Meccanica ed Ingegneria delle Rocce At: Torino

20. Bonini M, Barla G (2012) The Saint Martin La Porte access adit (Lyon-Turin Base Tunnel) revisited. Tunn Undergr Space Technol 30(12):38-54

21. Wang X, Lai J, Garnes RS, Lou J (2019) Support system for tunnelling in squeezing ground of Qingling-Daba Mountainous area: a case study from soft rock tunnels. Hindawi Adv Civil Eng 2019(8682535):17

22. Aygar E (2000) A critical approach to the new Austrian Tunneling Method in Bolu Tunnels, Master Thesis, Hacettepe University, The Department of Mining Engineering, Ankara, p 276.

23. Aygar E (2007) Investigation of the Bolu Tunnel Stability by Means of Static and Dynamic Analyses, PhD Thesis, Hacettepe University, The Department of Mining Engineering, Ankara, p 273.

24. Aygar EB, Gokceoglu C (2019) Ankara-Istanbul High Speed Railway Projects, The Problems Encountered at T13 Tunnel Fault Zone and Solution Suggestions, Proceedings of the 26th International Mining Congress and Exhibition of Turkey, 2019, p 197-205

25. Aygar EB, Gokceoglu C, (2019) Ankara-Istanbul High Speed Railway Project, T26 Tunnel Design and Evaluation of Supports Systems, Proceedings of the 26th International Mining Congress and Exhibition of Turkey, p 206-218.

26. Aygar EB, Gokceoglu C (2020) Problems encountered during a railway tunnel excavation in squeezing and swelling materials and possible engineering measures: a case study from Turkey. Sustainability 12:1166. doi:https://doi.org/ $10.3390 /$ su12031166

27. Jin-feng Z, Ze-hang Q, Xin-hai X, Guang huia C (2019) Face stability of a tunnel excavated in saturated nonhomogeneous soils. Tunn Undergr Space Technol 83:1-17

28. Hernández YZ, Farfána AD, Assis AP (2019) Three-dimensional analysis of excavation face stability of shallow tunnels. Tunn Undergr Space Technol 92:103062

29. Zhang Z, Jin X, Luo W (2019) Numerical study on the collapse behaviors of shallow tunnel faces under open-face excavation condition using mesh-free method. ASCE J Eng Mech 145(11):04019085

30. Yu L, Zhang D, Fang Q, Cao L, Zhang Y, Xu T (2020) Face stability of shallow tunnelling in sandy soil considering unsupported length. Tunn Undergr Space Technol 102:103445

31. Zhang S, He S, Qiu J, Xu W, Garnes RS, Wang L (2020) Displacement characteristics of an urban tunnel in silty soil by the shallow tunnelling method. Adv Civil Eng 2020

32. Morovatdar A, Palassi M, Ashtiani RS (2020) Effect of pipe characteristics in umbrella arch method on controlling tunneling-induced settlements in soft grounds. J Rock Mech Geotech Eng 12:984-1000

33. Huang Z, Zhang H, Fu H, Ma S, Liu Y (2020) Deformation response induced by surcharge loading above shallow shield tunnels in soft soil. KSCE J Civil Eng 24(8):2533-2545

34. Fugro Sial Geosciences Consulting and Engineering Ltd (2017) T4 Tunnel Geological-Geotechnical Investigation Report \& T4 Tunnel Project Report, p 280.

35. Carter M, Bentley P (1991) Soil Properties and their Properties. Wiley, New York, p 136.

36. Bieniawski ZT (1989) Engineering rock mass classifications. Wiley, New York

37. Grimstad E, Barton N (1993) Updating the Q-System for NMT. Proceeding on International Symp on sprayed concrete-modern use of wet mix sprayed concrete for underground support, Fagernes. 46-66. Oslo: Norwegian Concrete Assn

38. Terzaghi K (1946) Rock defects and loads on tunnel supports. In Rock tunneling with steel supports, Proctor RV, White TL (eds) 1, 17-99. Youngstown, OH: Commercial Shearing and Stamping Company

39. Das R, Singh PK, Kainthola A, Panthee S (2017) Numerical analysis of surface subsidence in asymmetric parallel highway tunnels. J Rock Mech Geotech Eng 9:170-179

40. Itasca (2002) Flac3d User Manual, Getting Started.

41. Zhang X, Wang M, Wang Z, Li J, Tong J, Liu D (2020) A limit equilibrium model for the reinforced face stability analysis of a shallow tunnel in cohesive-frictional soils. Tunn Undergr Space Technol 105:103562

42. Lyu H-M, Shen S-L, Zhou A, Chen K-L (2020) Calculation of pressure on the shallow-buried twin-tunnel in layered strata. Tunn Undergr Space Technol 103:103465

43. Fang X, Kikumoto M, Cui Y (2020) A theory of loosening earth pressure above a shallow tunnel in unsaturated ground. Int J Numer Anal Methods Geomech 44:1495-1508

44. Hoek E, Brown ET (1980) Underground excavations in rock. Instn Min. Metall, London

45. Hoek E (2007) Practical Rock Engineering, p 341, https://www.rocscience.com/assets/resources/learning/hoek/Pract ical-Rock-EngineeringFull-Text.pdf 
46. Hoek E (2012) Rock Support Interaction analysis for tunnels in weak rcok masses, https://www.rocscience.com/ documents/pdfs/rocnews/winter2012/Rock-Support-Interaction-Analysis-for-Tunnels-Hoek.pdf

47. Hoek E,Marinos P (2000) Predicting tunnel squeezing. Tunnels and Tunnelling International. Part 1 — November 2000, Part 2-December 2000.

48. Carranza-Torres C, Fairhurst C (2000) The elasto-plastic response of underground excavations in rock masses that satisfy the Hoek-Brown failure criterion. Int J Rock Mech Min Sci 36(6):777-809

49. Carranza-Torres C (2004) Elasto-plastic solution of tunnel problems using the generalized form of the Hoek-Brown failure criterion. Proceedings of the ISRM SINOROCK2004 Symposium China, May 2004. Edited by J.A. Hudson and F. Xia-Ting. Int J Rock Mech Min Sci 41(3), 480-481.

50. Carranza-Torres C, Diederichs M (2009) Mechanical analysis of circular liners with particular reference to composite supports. For example, liners consisting of shotcrete and steel sets. Tunn Undergr Space Technol 24:506-532

51. Vlachopoulos N, Diederichs MS (2009) Improved Longitudinal Displacement Profiles for Convergence Confinement Analysis of Deep Tunnels. Rock Mech Rock Eng 42(2):131-146

52. Unlu T, Gercek H (2003) Effect of Poisson's ratio on the normalized radial displacements occurring around the face of a circular tunnel. Tunn Undergr Space Technol 18:547-553

53. Hoek E, Carranza-Torres C, Diederichs MS, Corkum B (2008) Integration of geotechnical and structural design in tunnelling. In: Proceedings University of Minnesota 56th Annual Geotechnical Engineering Conference, 29 February 2008. Minneapolis, pp. 1-53

54. Komu MP, Guney U, Kilickaya TE, Gokceoglu C (2020) Using 3D Numerical Analysis for the Assessment of TunnelLandslide Relationship: Bahce-Nurdag Tunnel (South of Turkey). Geotech Geol Eng 38:1237-1254

55. Ghazavi M, Tavasoli O (2012) Characteristics of non-uniform cross-section piles in drivability. Soil Dynam Earthq Eng 43:287-299

56. Gokceoglu C, Turer A, Nefeslioglu HA, Turer D, Meral C (2016) Safety assessment of limestone-based engineering structures to be partially flooded by dam water: a case study from northeastern Turkey. Eng Geol 209:44-55

57. Tavasoli O, Ghazavi M (2018) Wave propagation and ground vibrations due to non-uniform cross-sections piles driving. Comput Geotech 104:13-21

58. Tavasoli O, Ghazavi, M (2019) Driving behavior of stepped and tapered offshore piles due to hammer blows. Marine Georesources and Geotechnology. pp 1-14.

59. Tavasoli O, Ghazavi M (2019) Performance evaluation of the lightweight concrete tapered piles under hammer impacts. Geomech Eng 18(6):615-626

60. Tavasoli O, Ghazavi M (2020) Effect of tapered and semi-tapered geometry on the offshore piles driving performance. Ocean Eng 201:107147

61. Zarei H, Moarefvand P, Salmi EF (2019) Numerical modeling of umbrella arch technique to reduce tunnelling induced ground movements. Environ Earth Sciences 78:291

62. Oke J, Vlachopoulos N, Diederichs MS (2012) Improved input parameters and numerical analysis techniques for temporary support of underground excavations in weak rock. In: RockEng. Edmonton.

63. Oke J, Vlachopoulos N, Diederichs MS(2013a) The reduction of surface settlement by employing umbrella arch systems. In: GeoMontreal 2013. Canadian Geotechnical Society, Montreal

64. Oke J, Vlachopoulos N, Diederichs MS(2013b) Modification of the supported longitudinal displacement profile for tunnel face convergence in weak rock. In: 47th US rock mechanics/geomechanics symposium. American Rock Mechanics Association, San Francisco

65. Oke J, Vlachopoulos N, Marinos V (2014) The pre-support nomenclature and support selection methodology for temporary support systems within weak rock masses. J Geotech Geol Eng 32(1):97-130

66. Oke J, Vlachopoulos N, Diederichs MS (2014b) Semi-analytical model of an umbrella arch employed in hydrostatic tunnelling conditions. In: 48th US rock mechanics/ geomechanics symposium. American Rock Mechanics Association, Minneapolis

\section{Publisher's Note}

Springer Nature remains neutral with regard to jurisdictional claims in published maps and institutional affiliations.

\section{Submit your manuscript to a SpringerOpen ${ }^{\circ}$ journal and benefit from:}

- Convenient online submission

- Rigorous peer review

- Open access: articles freely available online

High visibility within the field

Retaining the copyright to your article

Submit your next manuscript at $\boldsymbol{\nabla}$ springeropen.com 